University of Louisville

ThinkIR: The University of Louisville's Institutional Repository

Electronic Theses and Dissertations

8-2017

\title{
The mark of the Devil : medical proof in witchcraft trials.
}

Sarah Dunn

University of Louisville

Follow this and additional works at: https://ir.library.louisville.edu/etd

Part of the European History Commons

\section{Recommended Citation}

Dunn, Sarah, "The mark of the Devil : medical proof in witchcraft trials." (2017). Electronic Theses and Dissertations. Paper 2804.

https://doi.org/10.18297/etd/2804

This Master's Thesis is brought to you for free and open access by ThinkIR: The University of Louisville's Institutional Repository. It has been accepted for inclusion in Electronic Theses and Dissertations by an authorized administrator of ThinkIR: The University of Louisville's Institutional Repository. This title appears here courtesy of the author, who has retained all other copyrights. For more information, please contact thinkir@louisville.edu. 
THE MARK OF THE DEVIL: MEDICAL PROOF IN WITCHCRAFT TRIALS

By

Sarah Dunn

B.A., University of Louisville, 2014

\begin{abstract}
A Thesis Submitted to the Faculty of the
College of Arts and Sciences of the

University of Louisville

in Partial Fulfillment of the Requirements

for the Degree of
\end{abstract}

Master of Arts in History

Department of History

University of Louisville

Louisville, Kentucky

August 2017 

THE MARK OF THE DEVIL: MEDICAL PROOF IN WITCHCRAFT TRIALS

By

Sarah Dunn

B.A., University of Louisville, 2014

A Thesis Approved on

July 25,2017

By the following Thesis Committee:

Thesis Director

Dr. Blake Beattie

Dr. Genevieve Carlton

Dr. Pamela Beattie 


\section{DEDICATION}

For my parents, James and Becky Dunn, who gave infinite love, support, and encouragement when I needed it most, and for my granny, Edith Whaley, who taught me to dream big and to be myself without apology. Without you all, I could never have made it here. 


\section{ACKNOWLEDGMENTS}

For the past year and a half, I have been diving head first into research for this project, surrounding myself with books on witches, demons, and heretics. While worthwhile, it has been difficult, and I have many people to thank for their encouragement and assistance.

I would like to thank Dr. Blake Beattie, who inspired me to become a medievalist years ago in my undergraduate career, and perhaps more importantly, for putting up with my numerous questions about historical topics that most people would find unusual. I would also like to thank Dr. Genevieve Carlton, for helping me to form the initial research question that this thesis is based upon as well as for inspiring my interest in medieval and early modern witchcraft. Thank you as well to Dr. Pamela Beattie for agreeing to be on my thesis committee and for introducing me to the work of Marie de France.

Over the past two years, I have been lucky enough to learn from excellent historians in the History Department, including Brad Bowman, Jennifer Westerfeld, and Daniel Krebs. They have been instrumental in helping to shape my historical outlook. I am indebted as well to Lee Keeling, who guided me through life at the History Department with ease. Many thanks as well to my friends in the department, Hannah O’Daniel, Elle Rich, Mary K Marlatt, Jacob Burress, Javier Bonilla, and Julie Myers-Mushkin. Without the encouragement of this group of fellow historians, I would have become discouraged long ago.

Finally, I would again like to thank my parents, James and Becky Dunn, for their continued support and encouragement throughout the entirety of my graduate school career. 


\title{
ABSTRACT \\ “THE MARK OF THE DEVIL: MEDICAL PROOF IN WITCHCRAFT TRIALS”
}

\author{
Sarah Dunn
}

July 25,2017

This thesis examines the use of physical evidence to prove the identity of witches in witchcraft trials from approximately 1300 to 1650 in Western Europe. Throughout this period, trial records for accused witches and witchcraft texts include references to Devil marks. According to contemporary texts, these were physical marks on witches, which were visible to the human eye. Doctors and midwives verified these marks upon examination of the accused witch's body. In this instance, medical proof in the courtroom verified supernatural powers.

This thesis will analyze the intersection between medical and religious beliefs in the fourteenth through seventeenth centuries to evaluate the importance placed upon medical evidence by secular and ecclesiastical courts. Witch trials and holy autopsies will be examined to prove the central importance of physical evidence in determining an individual's religious status. This thesis will bridge the study of the history of medicine, the history of the body, and the history of witchcraft in order to examine a phenomenon that crossed all three categories. 
TABLE OF CONTENTS

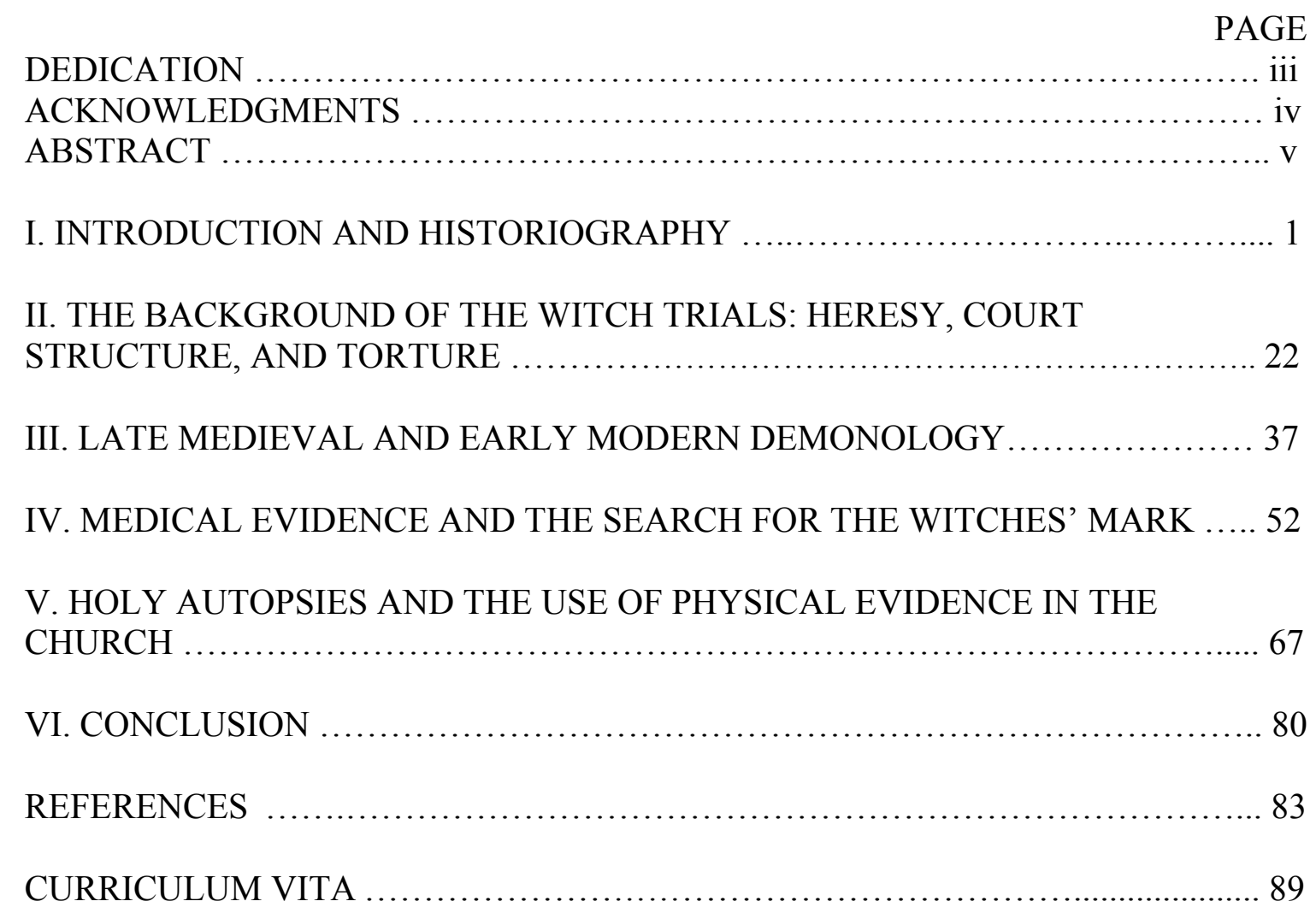




\section{INTRODUCTION AND HISTORIOGRAPHY}

An intense and widespread fear of witchcraft permeated society in the late medieval and early modern periods in Europe. From around 1300 to 1650 , citizens in England, France, Italy, and Germany were continually on guard against the danger witches posed in their communities. Throughout the Middle Ages and early modern period, men and women were accused, tried, and punished for the crime of witchcraft. The accused were put on trial, in various contexts, and expected to prove their innocence. Throughout the centuries, the evidence required to prove innocence became more and more difficult to obtain, while the evidence required to prove guilt became as easy as a body search.

Eventually, witch trials would take the very physical appearance of the accused into account. Not only was the outward appearance of an accused witch judged, but so was the entirety of their body. Accused witches would be stripped and searched for any sign of abnormality on their skin, which became known as witches' marks, witches' teats, devil marks, and suck spots. If one of these marks was found on the accused, the proof of demonic influence was evident, and they were convicted of the crime of witchcraft. To modern readers, this may seem like some sort of pseudo-science, but during the early modern period, the existence of a witch's mark was considered medical and scientific proof in a trial. In this thesis, the study of the body and the study of witch trials will be 
incorporated together in order to evaluate the importance given to physical evidence in the late medieval and early modern period during witch trials and holy autopsies. In witch trials, this medical evidence became indisputable physical proof of the diabolic activity. This physical proof was a way to prove logically that witchcraft, and by extension, the supernatural, was a real and present danger in the community.

Similarly, the importance and belief in saints and holy people existed in the same communities. Both witchcraft and sanctity reflected complex supernatural forces that were difficult to prove, but were easily believed. The need to prove the existence of both is inherent in human nature, but the utilization of bodily and physical proof is unique to early modern Europe's intense focus on the human body. Without the emphasis placed on both the physical nature of witchcraft and holiness, witch trials would have taken a completely different form. As it stands, physical evidence was the most important aspect of any trial, because physical proof on the human body of either witchcraft or holiness was the closest to a definitive proof of the supernatural any human could obtain. In a time period defined by uncertainty, anxiety, and constant change, the ability to prove the existence of the supernatural with physical evidence shaped the nature of criminal courts and autopsies irrevocably, allowing courts to prove the existence of the supernatural.

This thesis will focus on what are considered both the elite and popular witchcraft traditions. The primary texts utilized in this thesis consist mainly of demonological scholarship and witch trial records, which represent the elite and popular beliefs respectively. Demonological texts will be used to explain the prevalent beliefs in demons and witches that filtered down through the court system into the interrogators and demonologists present in the courtrooms. The most important primary demonological and 
theological texts used will be the Malleus Maleficarum, Cautio Criminalis, and the Compendium Maleficarum. The Malleus, written primarily by Heinrich Kramer, with assistance from Jacob Sprenger, in 1487 will be utilized to examine the widespread beliefs regarding the sexual nature of witchcraft, including penis stealing and the sexual relationships between witches, incubi, and succubi. ${ }^{1}$ The Malleus gives the modern reader insight into belief regarding witchcraft and the supernatural, but also into the role gender played into the trials. ${ }^{2}$ The Compendium Maleficarum, written in 1608 by Francesco Maria Guazzo, is not only an important demonological text, but also has a selection of woodcuts depicting common witchcraft-centered scenes. Three of these woodcuts will be examined in this work to show the relationship between witchcraft and heresy present in early modern witchcraft beliefs. Finally, Friedrich Spee's 1631 Cautio Criminalis will be examined as evidence of moderate voices in the argument against torture in witchcraft trials. Trial records will be used to show the beliefs in witchcraft that were popular among the accused, how trials were conducted, and what was used as evidence of witchcraft in a standard witchcraft trial. ${ }^{3}$

There are numerous works written on the European witch trials. The trials themselves and the beliefs surrounding them have many aspects historians have chosen to focus on, resulting in a vast historiography of the witch trials. Out of the plethora of

\footnotetext{
${ }^{1}$ For more information on the sexual nature of witchcraft, see Julia M. Garrett, "Witchcraft and Sexual Knowledge," Journal for Early Modern Cultural Studies 13, 1 (Winter 2013).

${ }^{2}$ For a study comparing witchcraft beliefs and charges against various heresies, see Norman Cohn, Europe's Inner Demons: The Demonization of Christians in Medieval Christendom, Revised Edition (Chicago: The University of Chicago Press, 1993).

${ }^{3}$ For collections of trial records, see Orna Alyagon Darr, Marks of an Absolute Witch: Evidentiary Dilemmas in Early Modern England (Burlington, VT: Ashgate Publishing Company, 2011); Marion Gibson, Early Modern Witches: Witchcraft Cases in Contemporary Writing (London and New York: Routledge, 2000); and Marion Gibson, Reading Witchcraft: Stories of Early English Witches (London and New York: Routledge, 1999).
} 
written work done on the witch trials, study on the physical body of witches and their importance in spurring demonological beliefs and in prosecution is not common. ${ }^{4}$ The history of witchcraft and the history of medical autopsies and anatomy rarely intermix. Therefore, this chapter will examine both the historiography of the witch trials and the historiography of medical dissection in the early modern period separately in order to show where this thesis fits within both historiographies. The works included in this historiography are in no way the full extent of the historiography on such topics as the witch trials, the study of anatomy, or saintly autopsies; they were chosen due to their prominence in academic circles, trusted authorship, and their ability to represent major aspects of the field.

Many early works from the 1960s and 1970s, while full of information and statistical data still relied upon today, are characterized by the methodological concerns of their eras. Most notably, the books from this time period often assume a superiority over the people they study. Many of the authors refer to witchcraft accusers and believers in witchcraft as primitive or as intellectually inferior, such as in Erik Midelfort's work discussed below. There was no emphasis on the study of the actual belief system of the age, instead using the examples of witch hunts as illustrations of a past that was believed to be inferior. Often, authors would write about the so-called backwards beliefs of their subjects and call such belief in witches primitive. Also, much of the historiography of the witch trials prior to the 1980 s does not have a nuanced, critical theoretical approach to the issue of gender in the witch trials, something of obvious importance in witchcraft theory.

\footnotetext{
${ }^{4}$ Studies of the physical body are done in works on possession, such as Robert Rapley, A Case of Witchcraft: The Trial of Urbain Grandier (Montreal: McGill-Queen's University Press, 1998) particularly due to the physical nature of the possessions and exorcisms.
} 
While the disproportionate gender bias in witch trials was noted, it was not analyzed critically until gender theory was applied later by other historians. Without a study of gender and its relationship to witchcraft, any analysis of witchcraft is incomplete.

Another trend in the historiography of the 1960s and 1970s was a theme of examining the power dynamic between the accusers and the accused. By examining the relationship between the witches and those who accused them, the power structure of medieval courts and communities was evaluated. This power structure relied on a mix of prestige, wealth, and class dynamics focused on by early historians of witchcraft.

The majority of historiography separates witchcraft belief into two distinct categories: elite and popular belief. Elite witchcraft belief concerns the ideas held by, as the name suggests, the elite members of society. This primarily included clergy, theologians, lawyers, and jurists. Their opinions on witchcraft and magic were influenced by heavy reading of scripture and scriptural commentary. Elite witchcraft beliefs are also separated by the literacy and knowledge of their believers. Almost exclusively written in Latin and compiled in expensive and rare volumes, elite belief was made up of a small but incredibly influential group of people. ${ }^{5}$ Popular belief was what other members of society believed; that is, the lay people, regardless of wealth or social status. Popular belief was influenced by elite belief, but did not solely consist of canonical opinion.

\footnotetext{
${ }^{5}$ For more information about elite belief, see the following: Stuart Clark, Thinking with Demons: The Idea of Witchcraft in Early Modern Europe (Oxford: Oxford University Press, 1997); Miguel De La Torre and Albert Hernández, The Quest for the Historical Satan (Minneapolis, MN: Fortress Press, 2011); Richard Kieckhefer's Forbidden Rites: A Necromancer's Manual of the Fifteenth Century (University Park, Pennsylvania: The Pennsylvania State University Press, 1997); and Frank Klassen, The Transformations of Magic: Illicit Learned Magic in the Later Middle Ages and Renaissance (Universtiy Park, Pennsylvania: The Pennsylvania State University Press, 2013).
} 
Often, aspects of elite belief were blended with traditional folk superstitions to create witchcraft beliefs that were quite different from elite opinion. ${ }^{6}$

In his 1971 book Religion and the Decline of Magic, Keith Thomas attempted to trace the popular belief in magic and superstitions through the lens of the Protestant Reformation. ${ }^{7}$ Thomas chose to analyze Britain from the fifteenth to the eighteenth century, a long enough time to analyze the changes brought on by Protestantism on popular and ecclesiastical belief. His research remained in a easily manageable timeline, and contained information on many topics within the said timeframe. Thomas' book was quite successful and well received by scholars.

What Thomas did very well, and what was new to his work at the time, was his focus on the popular and common beliefs in witchcraft. His first chapter was all about creating a cultural, social, and political context for the time period. Thomas analyzed all aspects of life during his period of study including health, medicine, class, and disaster in early modern English towns. According to Thomas' thesis, lived experience inevitably had ramifications on the beliefs of the time. Thomas argued that the beliefs he focused his research on had great social and intellectual implications, one of the central concerns being that of understanding and explaining luck and misfortune. ${ }^{8}$ This set up the following chapters well and gave both the general reader and historian a proper mindset

\footnotetext{
${ }^{6}$ For works that study the blend of elite and popular belief, see Owen Davies, Witchcraft, Magic and Culture: 1736-1951 (Manchester and New York: Manchester University Press, 1999) and Malcolm Gaskill's Witchfinders: A Seventeenth-Century English Tragedy (Cambridge: Harvard University Press, 2005).

${ }^{7}$ For more information on superstition and popular belief in witchcraft, see Michael D. Bailey, Magic and Superstition in Europe: A Concise History from Antiquity to Present and Werewolves, Witches, and Wandering Spirits: Traditional Belief \& Folklore in Early Modern Europe, edited by Kathryn A. Edwards (Lanham, Maryland: Rowman \& Littlefield Publishers, Inc., 2007).

${ }^{8}$ Keith Thomas, Religion and the Decline of Magic: Studies in Popular Beliefs in Sixteenth and Seventeenth Century England (London: Penguin, 2003), 5.
} 
for the continuing study throughout his book. Thomas explained quite deftly why a belief in magic could exist by showing that it had more to do with belief in God than it did in magic. Thomas alleged that the popular belief was that witchcraft and magic existed because it was allowed by God to exist.

Another early influential work on witchcraft was Erik Midelfort's Witch Hunting in Southwestern Germany published in 1972, a detailed history of witch trials in the southwest of Germany. Midelfort utilized a blend of historical and anthropological data analyses to explain the cause of such a high number of trials in such a relatively small area of Europe. Midelfort used an array of statistics in his book; in fact, much of his thesis depends upon them. Midelfort relied upon data, charts, and graphs to study witch trials, making his research almost entirely quantitative in nature.

The greatest strength of Midelfort's work was his continued insistence upon the differentiation between witchcraft beliefs across the continent. When discussing witchcraft theories in Germany, Midelfort asserted that most earlier scholars had wrongly tried to explain witchcraft theory as a singular belief. Instead, Midelfort argued, it should be viewed with more nuance to show the differences between regions. ${ }^{9}$ While Midelfort did not spend much of his book focused on the detailed social constructs of witchcraft, he did acknowledge the variations between witch beliefs across the continent. Midelfort was cautious in his distinctions, however, as he did contradict other historians who alleged a large shift in ideas as soon as Protestantism became popular. His argument was for gradual change amongst Germany, influenced by differing strands of Protestant thought.

\footnotetext{
${ }^{9}$ H.C. Erik Midelfort, Witch Hunting in Southwestern Germany, 1562-1684: The Social and Intellectual Foundations. (Stanford, CA: Stanford University Press, 1972), 65.
} 
Midelfort also devoted a chapter to trace the development of witchcraft beliefs from the early Middle Ages, through the Renaissance, and into the early modern period. He asserted that the second half of the sixteenth century witnessed a new period of religious fervor that coincided with a new fear of the devil. ${ }^{10}$ Midelfort argued that this led to a great rise in so-called devil-books. He relied upon these theological writings almost exclusively throughout his book, meaning that his view of witchcraft mostly focused on elite views. While he addressed the anthropological purpose, he believed witchcraft had in "primitive" societies in his Introduction, the rest of the book focused on elite theological and political writings and ideas.

While these two books represent excellent examples of early witchcraft study, the most well-known and influential historian of late medieval witchcraft is Richard Kieckhefer. His 1976 work, European Witch Trials, is still very influential in the historiography of witchcraft today. Kieckhefer focused on a time frame that had been less studied in regard to witchcraft: the fourteenth to the sixteenth centuries. Kieckhefer analyzed the cultural and theological contexts surrounding witchcraft belief and the origin of these beliefs.

Kieckhefer was one of the first to draw the distinction between elite and popular beliefs in witchcraft. The central thesis of his book rests upon this distinction. Kieckhefer proved how both traditions worked hand in hand to reinforce one another. Witches would be accused by members of their community who relied upon popular folk tradition. They would then be put on trial and evaluated by educated individuals who used the trial to reinforce their elite witchcraft beliefs. Kieckhefer not only asserted that there were two

${ }^{10}{ }^{10}$ H.C. Erik Midelfort, Witch Hunting in Southwestern Germany, 69. 
distinct types of witchcraft beliefs, but he also attempted to organize the various aspects of medieval witch belief into the two categories. He claimed that the idea of demonic witchcraft was entirely created by the elite tradition, whereas the folk tradition was simply concerned about what the Church believed was harmful natural magic. His emphasis on separating belief systems has allowed for historians following him to analyze the details of witchcraft belief at a much more minute level.

In Kieckhefer's Magic in the Middle Ages, published in 1989, the time period is much broader than his previous endeavor. In this book, Kieckhefer created an overview of magic from Late Antiquity to the Renaissance, with the majority of the focus on the central Middle Ages. His audience for this book was primarily undergraduates unfamiliar with magic in history, hence the broad range in time periods. Like all of his work, Kieckhefer focused on the cultural context of magic in each time period, explaining that magic was uniquely different in different time periods. Kieckhefer attempted to define the role of magic in medieval society, reinforcing his focus on the cultural. In so doing, he defined magic in general across all historical time periods as a sort of crossroads where religion, science, and popular culture intersect. ${ }^{11}$

Robin Briggs set out to write a cultural history of the European fear of witchcraft in his 1996 book, Witches \& Neighbors: The Social and Cultural Context of European Witchcraft. Unlike the majority of his peers and earlier historians, Briggs chose to write a macro-history encompassing the entirety of Europe and multiple centuries. By necessity, the book is less detailed than most. Briggs created a vast book, spanning centuries and

\footnotetext{
${ }^{11}$ Richard Kieckhefer, Magic in the Middle Ages. (Cambridge: Cambridge University Press, 1989), 1-2.
} 
continents. ${ }^{12}$ Between the geographical variety between witch beliefs and the time span of the book, Briggs was unable to devote enough time to any one specific topic.

Witches \& Neighbors is bereft of the trial records, both ecclesiastical and temporal, that a historian has come to expect in monographs about witchcraft. Briggs himself wrote in his introduction that he chose to adopt a more "primitive" approach to his work, choosing to write down what he believed to be true about the phenomenon. His intent was not to weigh the reader down with too much detail or micro-historical narrative, but to provide a general narrative of development in cultural practice throughout Europe. For historians who have a background in witchcraft, this should not pose a problem.

In one of Briggs' chapters, “The Projection of Evil,” Briggs highlighted the conundrum faced by people during the early modern period of how to deal with the beggars and poor families in their communities. Briggs did a nice job of examining the place Christian values and fear in magic had in the early modern mindset. This was where his cultural approach and broad sample area worked well. Briggs' focus on various economic groups is an example of newer works in the historiography, which take on variables such as educational level, economic background, and gender.

The most important aspect of this book is the emphasis on understanding the social and cultural climate surrounding the witch trials. Witches and Neighbors was not intended to be an all-inclusive exploration into the social world of witchcraft. Briggs attempted to remind historians of the value of macro-history in a generation focused on

\footnotetext{
${ }^{12}$ For more broad overviews of witchcraft in a similar style to Briggs, see Brian P. Levack, The Witch Hunt in Early Modern Europe, Fourth Edition (London and New York: Routledge, 2016) and Michael D. Bailey, Battling Demons: Witchcraft, Heresy, and Reform in the Late Middle Ages (University Park, Pennsylvania: The Pennsylvania State University Press, 2003).
} 
the glory of the micro-historical narrative. Briggs serves as a reminder to historians to remember context and to recall the lessons of macro-histories while examining more minute historical quandaries within the field.

Not all books on witchcraft have focused on broad social and cultural institutions. Instead of attempting to explain all witchcraft beliefs as in previous books, Hans Peter Broedel's book The Malleus Maleficarum and the Construction of Witchcraft, published in 2003, is an attempt to explain the Malleus as a product of two men with unique views on witchcraft. ${ }^{13}$ The book is not simply a guide to reading the Malleus, although it does give excellent insight into the logic of the treatise, but it is a guide to understanding the book's place in a complex history of inquisitions and popular superstitions. Broedel placed emphasis on understanding the Malleus Maleficarum in its specific historical context. By tracing the ideological roots of the Malleus and not simply writing a commentary on the words contained within it, Broedel wrote a valuable book for anyone studying medieval witchcraft, even those who study trials prior to the publication of the Malleus. A key element of this book, and work from this time period in the historiography, is the attempt at studying an element of the trials in its accurate historical context.

From the very beginning of the book, Broedel was a model historian. In his first chapter, he detailed his methods, approach, and arguments with excellent clarity. He included an incredibly detailed list of sources (almost as many as Kramer himself) and

\footnotetext{
${ }^{13}$ While Broedel's is one of the only books focused exclusively on the Malleus, Walter Stephens, Demon Lovers: Witchcraft, Sex, and the Crisis of Belief (Chicago and London: The University of Chicago Press, 2002) does analyze many prominent sections of the Malleus.
} 
made sure to not make caricatures of Kramer and Sprenger. Broedel walked the fine line of giving these historical actors personality but not turning them into characters.

In his writing, Broedel made sure to take into consideration both the elite and the common perceptions of witchcraft and incorporated them into his study. It would have been very easy to write a book about the Malleus and only focus on the elite theological meaning it had to the Inquisitors and Church officials of the time, but Broedel made sure to take all viewpoints into consideration. Based on the style of the Malleus, which was filled with popular witch beliefs and accounts of witchcraft, Broedel did it a great service in studying where these beliefs came from. As Broedel claimed, the views regarding witchcraft in the Malleus come from authors who viewed the world in a very similar way to their informants- the accused witches and heretics they interrogated. ${ }^{14}$ Broedel did well to explain not only their views on witchcraft, but also the different types of witchcraft Kramer and Sprenger believed existed. The classification of types of witches further shows the influence that popular belief had on the creation of the Malleus.

Particularly effective was Broedel's chapter about women and the admittedly misogynistic views Kramer and Sprenger expressed in the Malleus. ${ }^{15}$ Most importantly in this chapter Broedel did not support the blanket assumption that both authors must have simply hated women and therefore believed them to be witches, as other historians have done. Broedel did not conclude that the Malleus focused on women because all women were evil, but that most witches were women due to transgression of their social or sexual

\footnotetext{
${ }^{14}$ Hans Peter Broedel, The Malleus Maleficarum and the Construction of Witchcraft: Theology and Popular Belief. (Manchester, UK: Manchester University Press, 2003), 158.

${ }^{15}$ For more insight on gender and the witch trials, particularly of male witches, see Lara Apps and Andrew Gow, Male Witches in Early Modern Europe and E.J. Kent's Cases of Male Witchcraft in Old and New England (Manchester and New York: Manchester and University Press, 2003).
} 
roles in society. The virtuous woman was in no danger of being a witch; only the socially rebellious women who caused the greatest anxiety in the community could be witches. Broedel explicitly detailed the relationship between female sexuality and witchcraft, making the point that witches were not just bad; they were also believed to have entered into a sexual relationship with the Devil. Broedel skillfully navigated multiple viewpoints on the issue of gender in the witch trials and landed on an explanation that remained rational while still acknowledging the misogyny of the authors.

Broedel focused most of his analysis on Heinrich Kramer, since he was the one responsible for the majority of the book. Broedel's characterization of Kramer as unlikable, belligerent, and self-righteous certainly gives insight into the creation of the Malleus Maleficarum. His zealous nature, as described by Broedel, can be seen by any reader of the Malleus. It also explains the reaction among the educated elite to the book. For level-headed Inquisitors and theologians, the messages of the Malleus reflected the fanaticism that made Kramer so unpopular. It also explains his writing style; Kramer had to convince the reader completely, since he was hostile to any sort of criticism. ${ }^{16}$ A study of Kramer and his own personal beliefs was quite helpful in understanding the concepts discussed in the Malleus, particularly because it was so different from anything else being written about witchcraft at the time. Overall, Broedel authored a wonderfully nuanced overview of the time period in which the Malleus Maleficarum was written. He explained the common beliefs, the elite beliefs, and most importantly, how these beliefs were combined and written down by Heinrich Kramer and Jacob Sprenger.

\footnotetext{
${ }^{16}$ Hans Peter Broedel, The Malleus Maleficarum and the Construction of Witchcraft, 13.
} 
The historiography of the witch trials range widely in topic and analytical approach. It can be characterized by a few components. Most new work on witchcraft acknowledges witchcraft in its cultural and social contexts. Often this means separating the communities being studied into either economic, social, or gender groups. This type of treatment allows for a more detailed analysis of the cultural context surrounding the witch trials. Another similarity among works using this historiographical approach are the primary sources utilized by historians of witchcraft. Often the best primary documents are trial records and theological writings. In Kieckhefer's case, while trying to uncover more information about folk beliefs, he was only able to find a handful of pre-trial attestations from accusers that spoke to their beliefs on witchcraft. Unfortunately, given the nature of literacy in the Middle Ages, there are many more preserved records regarding learned witchcraft beliefs than there are folk beliefs. That, however, is a problem faced by most historians of the Middle Ages, who must contend with a lack of written sources documenting the lives of the common people.

The historiography of anatomy and dissection is less substantial, but still sufficiently rich to warrant discussion. Many historians broach the subject of holy autopsies from either a medical background or from a religious background. ${ }^{17}$ There is surprisingly little overlap between the medical and the religious backgrounds, but whether that is due to lack of interest or lack of effort is unclear. While historians like Katharine Park and Caroline Walker Bynum do an excellent job of making both the religious and the medical accessible to readers, very few other historians attempt to blend

\footnotetext{
${ }^{17}$ For work on holy autopsies see Katharine Park's work and Gianna Pomata, "Malphigi and the Holy Body: Medical Experts and Miraculous Evidence in Seventeenth-Century Italy," Renaissance Studies 21, 4 (September 2007), 568-586.
} 
the two like they have. Their works are the most complete studies on the holy female body and autopsies. Other historians mention the topic, but go into little or no detail. There are other works that slightly breach the subject, but do not specifically discuss gender and medicine.

Caroline Walker Bynum's multiple books and articles contend with the various ways that the people of the late medieval and early modern period viewed the religious and metaphorical importance of the female body as well as its physical importance. Starting in 1987 with her groundbreaking book, Holy Feast and Holy Fast: The Religious Significance of Food to Medieval Women, Bynum analyzed, as the title suggests, the importance and use of food for women in the Middle Ages. Not only did Bynum study the importance of food for religious women, but she also wrote a landmark work on the nature of female religious devotion in medieval Europe.

In Holy Feast and Holy Fast, Bynum described the role of women in the Church from the late twelfth to the fourteenth centuries. Bynum's main thesis was that food held a unique symbolic importance in the lives of medieval religious women. By controlling their intake of food, women were able to control their lives in a way in which they were previously unable. Bynum completely repudiated the prevailing view that female fasting was due to the dualistic world view imposed on them by the patriarchal hierarchy of the Church.

Bynum explained that women had a very deep relationship with food, both physically and spiritually. Women were able to relate to food in a way men were not. Food was the only physical aspect of life women were in complete control of, so fasting held both a religious and practical meaning. Bynum even found medical literature that 
described women in food-like ways, since their blood was believed to be turned into milk in order to nourish children. Bynum detailed the many miraculous religious women who produced milk and blood without explanation; similar accounts from holy autopsies are found in Katharine Park's work.

In her 1995 article, "Why All the Fuss About the Body? A Medievalist's Perspective," Bynum continued to elaborate points made in Holy Feast and Holy Fast, but she also wrote a detailed critique on the state of her field and how the female body was being studied. ${ }^{18}$ Bynum alleged that the study of the body is not just a study of the flesh or a study of gender, but should be a study of what she termed the "lived body." She also noted that the majority of the research being done on the body at the time of her writing was being done on sex and gender. Bynum called for historians to begin to study what the body meant in practice, not just in theory.

In Katharine Park's 2006 book Secrets of Women: Gender, Generation, and the Origins of Human Dissection, Park focused on the importance placed on the female body in religious and secular contexts as well as the emphasis placed on the dissection of female bodies. ${ }^{19}$ Park evaluated the role anatomy played in the late thirteenth through the early sixteenth centuries. ${ }^{20}$ According to Park, the historiography prior to her book included incorrect assertions- that anatomy and dissection were forbidden by the Church

\footnotetext{
${ }^{18}$ For more by Walker Bynum on the body, see Fragmentation and Redemption: Essays on Gender and the Human Body in Medieval Religion (New York: Zone Books, 1991) and The Resurrection of the Body in Western Christianity: 200-1336 (New York: Columbia University Press, 1995).

${ }^{19}$ For more of Park's work on the dissection and autopsy of the female body, see "The Criminal and the Saintly Body: Autopsy and Dissection in Renaissance Italy," Renaissance Quarterly 47, 1 (Spring 1994): 1-33 and "Holy Autopsies: Saintly Bodies and Medical Expertise, 1300-1600," in The Body in Early Modern Italy, edited by Julia L. Hairston and Walter Stephens (Baltimore, MD: The Johns Hopkins University Press, 2010), 61-73.

${ }^{20}$ For more work on autopsies, see Helen MacDonald, Human Remains: Episodes in Human Dissection and Mary Lindemann's Medicine and Society in Early Modern Europe (Victoria, Australia: Melbourne University Press, 2005).
} 
and that these dissections were only performed on men. Park argued that by the late thirteenth century autopsies and dissections were already being practiced in Italy. Park wanted to restore the social and religious context that both criminal dissections and private autopsies were a part of. ${ }^{21}$ Park contributed greatly to the production of knowledge surrounding female bodies in late medieval and early modern Europe, the distinction between autopsy and dissection, and the importance of both in early modern Europe. $^{22}$

Peter Brown's 1980 book The Cult of the Saints is an excellent study in the creation of a cult of saintly worship during the early centuries of Christianity. Brown primarily focused his work on the Mediterranean from the $4^{\text {th }}$ to the $6^{\text {th }}$ centuries CE and included comparisons between Christianity, Judaism, and later, Islam. Brown's goal was to explain various factors that led to the rise in importance of the saints and how this cult was accepted by both the elite and common Christians. While The Cult of the Saints has nothing directly to do with holy autopsies, it is useful to show how important the physical body of saints were to the Church, and how the relics and bodies of saints were treated.

Brown placed a great emphasis on the importance of understanding the common views on religion and the importance of saints. Brown's focus on saints emphasizes the importance of their materiality in the medieval world. The physical remains of the saints held great power, proving the importance of the physical. Brown challenged the two-tier system of understanding early Christianity, so named because of the two main branches of religion: the popular (or "vulgar") and the elite. This model insinuates that change

\footnotetext{
${ }^{21}$ Katharine Park, Secrets of Women: Gender, Generation, and the Origins of Human Dissection. (New York: Zone Books, 2006), 16.

${ }^{22}$ In addition to Park, Monica Green has written extensively on medical theories surrounding women in the late medieval and early modern period.
} 
would come to religion from the elite and then it would influence the beliefs of those below. Brown argued that the relationship between the common people and the elite was much more nuanced, and that both groups engaged in constant negotiation with one another. By exploring the impact popular religion had on Christianity as a whole, scholars are able to give agency to the common people.

While Brown's book primarily focused on the Late Antique period, it also gave insight into medieval views on saints, cemeteries, and shrines. Considering the importance of pilgrimages and relics in the Middle Ages, this book is quite valuable for anyone studying the time period. What was formed during the period Brown focused on is the foundation of the medieval Catholic Church. The growth in importance of specific bishoprics, the creation of large shrines, and the emphasis placed upon saints, among others, all helps to explain the culture of the Middle Ages.

Brown was also very interested in the delineation between public and private domain, which makes sense considering the cult of the saints is based mainly on the earthly remains of dead human beings. Shrines, churches, and even the saints' bodies all took up space. Whether it be in regard to the democratization of mourning rituals or the actual space of the tombs in regard to the cities of the living, Brown believed how space was used was incredibly important.

The greatest strength of The Cult of the Saints was the way Brown utilized his chosen primary sources. Every chapter utilized a wide selection of texts from early Church fathers and theologians. Brown even incorporated Jewish and Islamic texts in order to give a fuller context for the lives of the people in the Mediterranean. While some sections of the book do lean quite heavily upon quotes, they are never without cause. 
Particularly compelling were the sections regarding the ceremonial customs practiced by people to celebrate and honor the deceased in the second chapter. His choice of quotations illustrated the importance people of multiple time periods and faiths placed upon the grave, particularly when it came to the question of who controlled the grave and celebrations.

Now that the current state of both fields has been covered, it is time to make suggestions for where each could begin to grow. For the study of autopsy and dissection, the most pressing matter is to attempt to integrate both the scientific and the religious historians together. While much easier said than done, there should be a balance between the concise anatomical jargon used by the medical side of the field and the strict religious focus of the Church historians' side. This type of scientific history needs both the medical detail and the religious background from both sides to truly flourish. While in many other subsets of the study of early modern Europe, historians have removed religion as a singular cause, in the fear or interest in autopsies, historians continually return to religion as a primary cause. While religion cannot, and should not, be removed from consideration while researching the topic of autopsies, it should be included with a list of other influencers such as gender, society, and politics.

The scholarly literature on religious autopsies is very sparse. Historiographically speaking, very few historians apart from Katharine Park focus their work on holy autopsies. There is a great deal of room for growth within the field. If historians apply more interdisciplinary and cultural history models, there could be a huge market for research. Historians could use even more techniques from women's and gender studies to make a better picture for what life was truly like for these women who ended up 
receiving the holy autopsies, or even the women who ended up being dissected. When researching early modern beliefs on the body, there are multitudes of results relating to the body as a sexual object. Studying the body as a metaphor for sexuality is a booming field in recent historical study, no matter the time period. While this work is important, there is strikingly less work written on the human body as exactly what it is: a body. Certainly not for lack of primary sources and evidence, the draw away from treating the body as a medical and scientific reality lies somewhere else. Most likely, the sexual body and the study thereof is a more popular trend in historical circles. Taking the approaches detailed above, historians should attempt to write histories of the body as a physical object.

There is considerable misinformation due to nineteenth century historians spreading inaccuracies about the true feelings of the people in the early modern period about autopsies and dissections. In order for historians to be able to understand the science and medical beliefs of the time, they must sift through inaccurate information about the mindset of the European people in regard to dissection. There is plenty of room for new and more nuanced work regarding women's place in autopsies, in dissections, and in medicine itself. If future historians can adapt some of the suggestions detailed above, the field will be able to grow exponentially. Study needs to be done on all aspects of women in regard to medicine and autopsies, not only saints. With Katharine Park and Caroline Walker Bynum paving the way, the future study of female autopsies and dissections can grow in earnest.

While the field of witchcraft studies already has a vast historiography, there is still room to expand analysis and grow. Primarily, new historians studying witchcraft could 
focus on continuing to incorporate interdisciplinary studies into their works. One field that is less popular to incorporate is medical history. The medical analysis of witchcraft would lend itself to studying the physical aspect of witches. Historians could expand their research into the physical nature of witchcraft, as this thesis attempts to do.

By studying the physical nature of witchcraft, historians could branch into the importance placed on strip searches in trials, torture of accused witches, execution methods for witches, and of course, the study of witches' marks. Since the late medieval and early modern demonologists focused so much of their writing on the physical nature of a witch's body, it stands to reason that historians studying the witch trials should focus on the physical nature of the witch as well. Medical evidence is often cited in trial records, but rarely combined with the study of the witch trials. This thesis attempts to bridge the gap between the study of the physical body and the study of the witch trials in order to properly analyze the importance placed upon physical evidence during a witch trial. 


\section{THE BACKGROUND OF THE WITCH TRIALS: HERESY, COURT STRUCTURE, AND TORTURE}

Before any aspect of a witch trial record can be properly discussed, the nature of a late medieval or early modern criminal trial must be understood and the mechanisms of the trials themselves must be evaluated. How the trials worked played a pivotal role in the prosecution and conviction of witches. The types of evidence and testimony available to accusers and the accused is important to any criminal case, but is particularly important for a case with the nebulous concept of supernatural powers as its basis. This chapter will also examine the historical link between heresy and witchcraft, which is important in explaining the physical nature of witchcraft and the danger it posed to the community. Finally, this chapter will also examine where certain witchcraft beliefs originated, particularly those where the witch is performing physical deeds of diabolism. This chapter will provide a basis to start the analysis of witches' marks, witchcraft, and holy autopsies and their relationship to the physical body in the rest of the thesis.

Prior to the witch panics in the late medieval and early modern periods, there was another great fear in the collective European consciousness. Heresy, defined as a choice to disagree with established religious doctrine, was considered the most dangerous force facing Christian Europe. ${ }^{23}$ Starting in the twelfth century, heresy was tied closely with

\footnotetext{
${ }^{23}$ Michael C. Thomsett, Heresy in the Roman Catholic Church: A History. (Jefferson, N.C.: McFarland, 2011), 18.
} 
sorcery, the intellectual use of demonic magic. Those charged with sorcery were almost always charged with heresy as well. Over time, as beliefs in sorcery grew into beliefs in demonic witchcraft, the link with heresy remained.

Heresy was often a very physically demanding act. While heresy was defined as incorrect religious beliefs, often the most dangerous part of the heresy was how it dealt with the physical world. In some heresies, such as Manichaeism and Catharism, followers would refuse to eat meat, remain chaste, and reject certain aspects of ceremonies and sacraments of the Church. ${ }^{24}$ Another medieval heresy, known as the Free Spirits, professed that because true salvation was found in accepting God's omnipotence, baptism and communion were useless, even going so far as to attest that the physical body of Christ lost its significance. ${ }^{25}$ By rejecting these very physical and visible aspects of life in Western Christendom, heretics were rejecting the very nature of the Church and its ceremonies.

Catharism was another prevalent late medieval heresy, spreading quickly and easily across southern France, northern Italy, northern Spain, and the southern Rhineland. Declared a threat due to their rejection of basic tenets of Christian doctrine, Catharism became feared by the Church. Along with that fear came rumors of diabolic activity. The supposed diabolic nature of the Cathars mirrored the diabolic nature of witchcraft. Cathars were accused of communing with the devil and performing rituals to honor him. ${ }^{26}$ This most likely was caused by a misrepresentation of the Cathar belief in dualism, the belief that God and Satan were equal and opposing forces, representing the opposition

\footnotetext{
${ }^{24}$ R. I. Moore, “The Origins of Medieval Heresy,” History 55, 183 (1970), 21.

${ }^{25}$ Claus-Peter Clasen, "Medieval Heresies in the Reformation," Church History 32, 4 (December 1963), 393.

${ }^{26}$ Lucy Mair, “Witchcraft, Spirit Possession and Heresy,” Folklore 91, 2 (1980), 230.
} 
of the spiritual world and the temporal world, respectively. ${ }^{27}$ This devil-worship then became its own heresy, one that over time became tied with accusations of witchcraft. It stood to reason that if a heretic worshipped the Devil exclusively, then they must get something in return. That gift from Satan was the possession of magic. From approximately the thirteenth century, the Church began to consider witchcraft as an explicit rejection of God and an alignment with Satan- in other words, a heresy. ${ }^{28}$

One of the most famous groups accused of heresy in the early fourteenth century was the Knights Templar. Originally a crusading order, the Templars were targeted by King Philip IV of France for their power and wealth. Rumors about their alleged deviant and heretical behavior had surrounded the Templars for many years, which made Philip's attack on them all the more successful. According to trial records from the massive purge of Templars by Philip in 1307, Templars, under torture, admitted to obscene initiation rites. Those who confessed said that new members were required to spit, urinate, or trample the cross, kiss the officiate on the backside, and worship a demon named Baphomet, who appeared to them in the form of a black cat. ${ }^{29}$ In particular, the trampling of the cross and the obscene kiss were concepts that did not disappear with the demise of the Templars. While the validity of the charges is subject to debate, it is telling that the heresy of the Templars was constructed to include both heretical and magical elements, according to charges leveled against them by their political enemies. ${ }^{30}$

\footnotetext{
${ }^{27}$ Emily McCaffrey, "Imagining the Cathars in Late-Twentieth-Century Languedoc," Contemporary European History 11, 3 (August 2002), 410.

${ }^{28}$ Ibid., 230.

${ }^{29}$ Arno Karlen, “The Homosexual Heresy," The Chaucer Review 6, 1 (Summer 1971), 57.

${ }^{30}$ Helen Nicholson, The Knights Templar: A Brief History of the Warrior Order (London: Constable \& Robinson, 2010), 239.
} 
The perceived threat heresy posed to medieval and early modern Europe was a prerequisite for later demonology and judiciary operations, including witch trials. ${ }^{31}$ Once diabolic witchcraft entered the late medieval and early modern consciousness, it began to be considered as the most dangerous type of heresy. Not only was witchcraft considered the worship of Satan and rejection of all Christian beliefs, but it was also something that could be utilized to endanger the lives of average people in the community with evil magic, called maleficium.

Some very clear representations of witchcraft as heresy are represented in Francesco Maria Guazzo's 1608 witchcraft manual, the Compendium Maleficarum. The Compendium was written after the link between witchcraft and heresy was made, showing the witches engaging in activities that were taken directly from charges made against heretics in the thirteenth century. By the time Guazzo wrote the Compendium, the general accusations charged against witches at their meetings had become standardized, including the seduction, the Satanic pact, the dance, and the baptism. ${ }^{32}$ Since the activities of witches became so standardized, it made it easier to illustrate what was believed to occur when witches met the Devil.

In Figure 1, the witches are seen waiting to receive baptism from Satan himself. The male witch in the forefront is kneeling, with hands clasped and head bowed in a mockery of prayer, while Satan is baptizing him. This depiction served multiple purposes. First and foremost, this image was used in the Compendium as proof of the infernal relationship that the witch had entered. Guazzo utilized woodcuts in the

\footnotetext{
${ }^{31}$ Malcolm Gaskill, "The Pursuit of Reality: Recent Research into the History of Witchcraft," The Historical Journal 51, 4 (December 2008), 1076.

${ }^{32}$ Lyndal Roper, Witchcraft and the Western Imagination," Transactions of the Royal Historical Society sixth series, 16 (2006), 123.
} 
Compendium as illustrations of the devious behavior witches engaged in, but also as a type of evidence to prove his points. Baptism, whether Christian or demonic, was a serious act meant to prove the devotion of the person being baptized. Secondly, Satan and the witches are participating in an inversion of the traditional baptismal ceremony of the Catholic Church. Satan is baptizing the witches into the ranks of the damned, marking them not only as non-Christians, but also as his servants. This inversion of one of the most important sacraments of the Catholic Church was used as proof of a witch's ultimate evil. In being baptized by Satan, the men and women in the engraving are not only becoming witches, but becoming heretics as well, since they actively chose to reject the teachings of the Catholic Church.

Figure 2 shows another very physical act being conducted by the heretics. Their animated stomping on the cross would be shocking to an early modern audience. This blasphemous behavior again emphasizes the heretical nature of the witches. By stomping on the cross, the heretics are metaphorically stepping on Christ Himself. Since the cross is the representation of the physical, bodily torture Christ endured, stomping on it represents a rejection of Christ's passion. Of course, rejecting Christ was also a sign of heresy. Many medieval heresies debated the true nature of Christ, whether he was fully human, fully divine, or a mix of both. In the Catholic view, this questioning of Christ's nature was proof of their rejection of the true Christ, and evidence of their unorthodox beliefs. This behavior was similar to one of the initiation rites performed by the Knights Templar in their meetings. The behavior remained the same, namely the desecration of the cross, but the group it was attributed to switched from heretics to both heretics and witches. 
Finally, in Figure 3, the heretics are seen engaging in the osculum infame, or the shameful kiss. It was believed that witches would greet Satan, and often other demons, by kissing them on the behind, instead of on the mouth. This kiss reinforced the danger of witches, since it was the inversion of a proper greeting. This belief in the osculum infame stemmed from rumors that members of the Knights Templar engaged in similar activities in their meetings, kissing both the officiating Templar at their meetings and the demoncat Baphomet. This inversion of traditional behavior again emphasized the dangerous and immoral behavior engaged in by heretics and witches alike.

The representations in Guazzo's Compendium Maleficarum show multiple ways it was believed witches engaged in heretical behavior throughout their meetings with Satan. Not only did these witches engage in behavior directly meant to contradict Catholic tradition and teaching, but they also practiced behavior already tainted by association with known heresies such as the Templars and the Cathars. Guazzo drew his inspiration for his woodcuts from popular existing beliefs about what occurred at a witches' sabbath, meaning these heretical behaviors had already been transferred from heretics to witches in both elite and popular witchcraft beliefs. 
Figure 1:

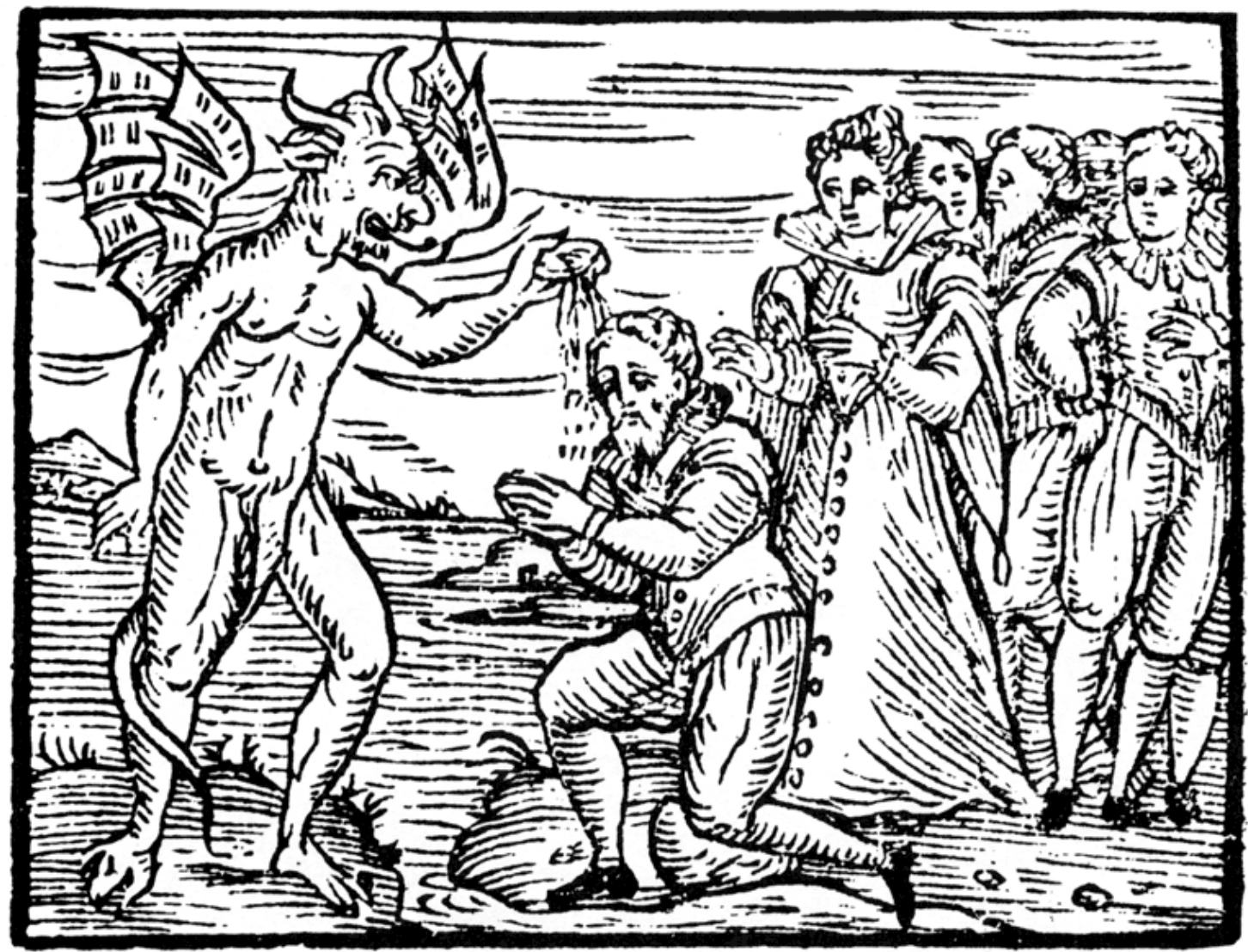


Figure 2:

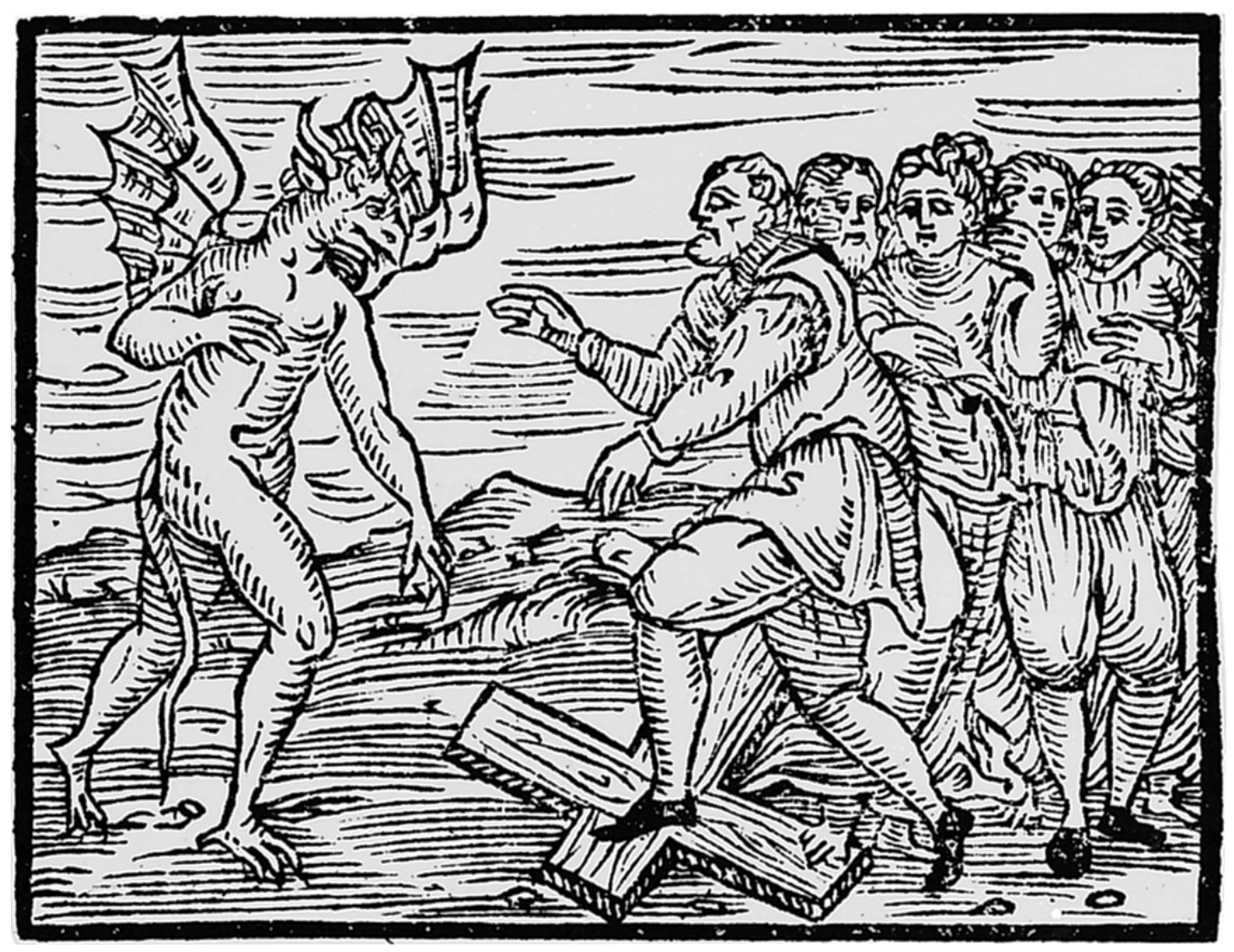


Figure 3:

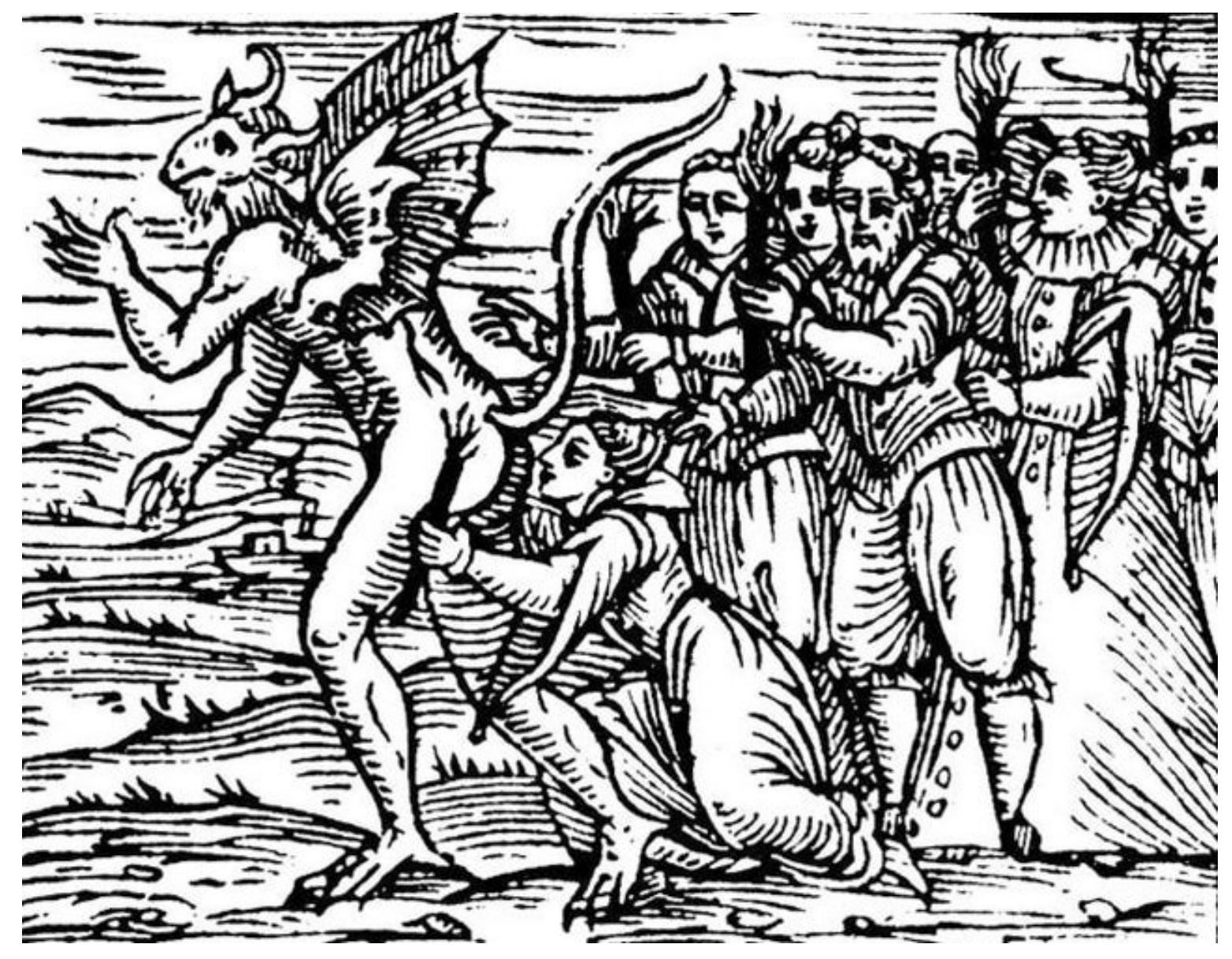

Given the association of witchcraft with heresy, it is unsurprising that court

procedures in witchcraft trials would draw heavily from proceedings against heretics. In

both secular and inquisitorial court cases, testimony of eyewitnesses, character witnesses,

and the bewitched, was of vast importance. In the early Middle Ages, many trials were

decided by ordeals. Ordeals became consistently used after 1166 and the Assize of

Clarendon in England, and were also popular on the European continent. ${ }^{33}$ These ordeals

were a way for the law to allow God to prove either the innocence or the guilt of the

\footnotetext{
${ }^{33}$ Margaret H. Kerr, Richard D. Forsyth, and Michael J. Plyley, "Cold Water and Hot Iron: Trial by Ordeal in England," The Journal of Interdisciplinary History 22, 4 (Spring 1992), 573
} 
accused. Typically, these ordeals were physical, the most well-known being trial by fire, trial by water, and hot iron tests. ${ }^{34}$ These trials by ordeal were not frequent, but were only used when all other judicial options to determine guilt had been exhausted..$^{35}$ After the Fourth Lateran Council in 1215, ordeals were forbidden. ${ }^{36}$ The end of ordeals meant both a change in the rules of evidence and a change in the nature of trials. After ordeals were removed from the legal routine, something had to take its place. Statutory proof became that replacement. ${ }^{37}$ Statutory proof eliminated the need for ordeals, instead requiring evidence of a non-supernatural origin to be presented to the judge. The system of statutory proof meant both the elimination of judicial discretion and the need for noncircumstantial evidence to definitely convict the accused. ${ }^{38}$ The law of statutory proof required objective evidence in order to convict a criminal. For witch trials, this objective statutory proof was used as proof of witchcraft and as proof of the supernatural.

In the majority of legal cases, proof was fairly easy to obtain, but for something like witchcraft, insurmountable proof was difficult. Thus, testimony by eyewitnesses was key for a successful witch trial. Often the accused's character would be put on trial: were they known for being religious, did they get along well with neighbors, and particularly for women, did they behave in a manner appropriate for their gender? Since most early witch trials were in small towns and villages, it was not difficult to find someone who knew details about the accused's life. Friedrich Spee, a German Jesuit, wrote an

\footnotetext{
${ }^{34}$ Virpi Mäkinen and Heikki Pihlajamäki, "The Individualization of Crime in Medieval Canon Law," Journal of the History of Ideas 65, 4 (October 2004), 537.

${ }^{35}$ Heikki Pihlajamäki, "Swimming the Witch, Pricking for the Devil's Mark': Ordeals in the Early Modern Witchcraft Trials," Legal History 21, 2 (August 2000), 38.

${ }^{36}$ Kerr, Forsyth, and Plyley, "Cold Water and Hot Iron: Trial by Ordeal in England," 573.

${ }^{37}$ Heikki Pihlajamäki, “'Swimming the Witch, Pricking for the Devil's Mark': Ordeals in the Early Modern Witchcraft Trials," 38.

${ }^{38}$ John H. Langbein, Torture and the Law of Proof: Europe and England in the Ancien Régime (Chicago and London: University of Chicago Press, 2006), 6.
} 
influential treaty on witch trials in 1631 titled Cautio Criminalis, or a Book on Witch Trials. In this treaty, Spee not only wrote about his beliefs on witchcraft, but also wrote about the legal procedures surrounding the witchcraft accusations. Spee in particular wrote in condemnation of the ease with which civilians were able to accuse and prove witchcraft. As Spee wrote, "if the possessed should say anything, or if the malign and spurious (for it is never proven) rumor of the day falls heavily upon some poor, common Gaia, then she is the first [to be condemned]. ${ }^{, 39}$ According to Spee, rumors and public opinion held great importance in accusations of witchcraft. Of course, the defendant was allowed a defense, but often, once a community's mind was made up regarding the character of the accused, little the defendant could say would change their minds. Eyewitness testimony and character references were widely used and accepted as infallible proof of guilt in witch trials, since it was falsely assumed that the witness would have no reason to lie or invent a false narrative. This type of testimony is what most of a witch trial rested upon.

One type of objective evidence used in witch trials was the existence of a witch's mark. In order to search for a witch's mark, a physical sign of witchcraft, the accused was required to be stripped and examined. This meant that detailed strip searches of the accused's body were an important aspect in any witch trial. It was believed that if the witch's mark was not found and identified, then the witch would be able to withstand her interrogation, and likely torture, and would be found innocent. Thus, the search for the witch's mark was one of the most important parts of the trial for any witch. That is not to

\footnotetext{
${ }^{39}$ Friedrich Spee von Langenfield, Cautio Criminalis, or a Book on Witch Trials, ed. Marcus Hellyer (Charlotsville, VA, 2003), in The Witchcraft Sourcebook, ed. Brian P. Levack (New York and London: Routledge, 2004), 147.
} 
say, however, that if a mark was not found that the accused would be released. It was believed that the witch had the ability to hide their true nature, and with the possession of a witches' mark, the witch had the power to sustain questioning as long as necessary, as described in multiple sections of the Malleus Maleficarum. Therefore, it was believed that torture was necessary to force a confession from the witch. In this thesis, torture is considered as anything harming the physical or mental safety of the accused.

While torture was not applied in every case, and certainly some witches confessed to the details of their supposed nocturnal activities quite readily, the threat of confessions tainted by the application of torture was seen as problematic to some judicial scholars such as Friedrich Spee. The use of torture was governed by its own rules, treaties, and officials, developed in northern Italy from the Roman inquisitorial tradition in the thirteenth century and spread rapidly throughout the rest of Europe. ${ }^{40}$ Torture was not $^{-1}$ haphazardly applied at the whim of the interrogator, but was instead regulated and applied with great precision. From as early as 1468 witchcraft was considered a crimen exceptum, which was a crime so heinous that it directly offended God. Therefore, traditional court procedures could be suspended to ensure a confession. ${ }^{41}$ The regulation of torture did not necessarily apply to witches.

There were many methods of torture employed by the courts during witch trials. These tortures were meant to break the hold the Devil had over the witch and force them to give in to the torment they were enduring. Confessions were the ultimate goal of an interrogator. While a witches could be convicted while still protesting their innocence, a confession confirmed the ideas already held by the interrogators, witch hunters, and

\footnotetext{
${ }^{40}$ John H. Langbein, Torture and the Law of Proof, 3.

${ }^{41}$ Rossell Hope Robbins, "The Imposture of Witchcraft," Folklore 74, 4 (1963), 553.
} 
demonologists. The physical torture of accused witches was a direct effect of the increased emphasis on eyewitness testimony and confessions held in the judicial process.

A popular torture technique was the denial of sleep, which blended mental and physical torture into a very potent compound. Sleep deprivation was used in multiple countries including Italy and England. ${ }^{42}$ The specific details of how the accused was kept awake could vary depending upon location and even the individual torture practitioner, but the general technique would remain. According to the trial records, often the accused would be kept awake for upwards of 40 hours before interrogation would officially begin.

Another popular method of exacting confessions was simply the threat of physical torture. ${ }^{43}$ While, by the strictest definition, no torture would take place, again the mental stress placed upon the accused would be more than enough to convince them to confess. Particularly if there was a possibility of lenience in punishment, confessing before any torture was applied was a worthwhile option.

Actual physical torture methods varied widely from location to location, but often they focused on damaging the internal body. One such torture method was the strappado, also known as the manacles in England. ${ }^{44}$ The strappado involved placing the accused's wrists behind their backs, hoisting them up in the air by their wrists, and then either dropping them quickly or hitting the rope holding them with a stick. The jerking caused by these actions would over time cause the shoulders to pop out of their sockets and damage the arms irrevocably. Since no blood was drawn, the torturer could still claim no

\footnotetext{
${ }^{42}$ Camille Naish, Death Comes to the Maiden: Sex and Execution 1431-1933 (London: Routledge, 1991), 27.

${ }^{43}$ John H. Langbein, Torture and the Law of Proof, 101.

${ }^{44}$ Ibid., 101.
} 
significant torture was applied. That, coupled with the relative ease and cost effectiveness of the torture, made it very popular.

By the sixteenth century, there were advocates for the removal of torture from the repertoire of an investigator or inquisitor. One of the most well-known of those in the seventeenth century who questioned the efficacy of torture was Friedrich Spee. Within Cautio Criminalis, Spee not only detailed the problems with torture in trials, but also detailed issues he had with the structure of witch trials as a whole. In his description of the way a typical witch trial worked, Spee noted that if an accused witch showed fear, she had the right "naturally so since she has heard what severe tortures are normally used in these matters.. ${ }^{45}$ Spee, along with a growing number of critics, argued that torture would produce false accusations at an impressive speed. Spee then detailed how the torture sessions worked. He wrote,

Before he tortures her, the torturer leads her aside, so that she may not strengthen herself against the pain with some kind of magic charm, he shaves and searches her entire body - even that part by which her sex shows is most impudently searched. Of course to this day nothing has ever been found. . . Once Gaia has been searched and shaved, she is tortured so that she recounts the truth, that is, she simply pronounces herself to be guilty. Whatever else she might say is not the truth, nor can it be. However, they subject her to torture of the first kind, that is, the more mild kind, which one should understand this was: it actually is very severe, but it is mild in comparison with the following kinds. Therefore, if she confesses they say and circulate that she confessed without torture. ${ }^{46}$

Torture was quite often used in large secular trials, according to Spee, and was used to generate confessions, regardless of actual guilt.

The use of torture is important to this thesis for multiple reasons. First, it shows how the belief in witchcraft continued to sustain itself throughout the centuries. These

\footnotetext{
${ }^{45}$ Friedrich Spee von Langenfield, Cautio Criminalis, in The Witchcraft Sourcebook, ed. Brian P. Levack, 147.

${ }^{46}$ Ibid., 148.
} 
confessions were often used as proof that what demonologists alleged about witches was real. Accused witches would not have as readily confessed to the allegations laid against them by demonologists if they were not threatened with the threat of torture. Secondly, it allowed the precedent for the focus on the body of the accused witch. Here Spee detailed an account where the witch was stripped and searched for anything that could have protected her against the harm and pain of the torture, most likely a Devil mark.

Ultimately, the link between witchcraft and heresy, trial structure, and the use of torture were all factors in the use and importance of physical proof in the late medieval and early modern period. The trial structure of early modern courts made it possible for strip searches and searches for witches' teats to enter the judicial consciousness. It was a continuation of ordeals from the twelfth and thirteenth centuries, only allowed to persist because of the need for statutory proof. ${ }^{47}$ This physical proof was deemed viable because it was proof of the supernatural or unexplained, thus establishing it as proof of witchcraft.

Without the establishment of the physicality of witchcraft through its link with heresy, witchcraft would not have been considered a physical crime, meaning that physical proof would not have been as easily obtained. Similarly, the importance placed on eyewitness testimony in the late medieval judicial system encouraged the belief in bodily evidence of witchcraft that was visible to the naked eye. Once linked with the danger of heresy, the fear of witchcraft became a fear in both the supernatural nature of magic and the non-Christian element of heresy, combined into the singular crime of witchcraft.

\footnotetext{
${ }^{47}$ Heikki Pihlajamäki, “'Swimming the Witch, Pricking for the Devil's Mark': Ordeals in the Early Modern Witcheraft Trials," 36.
} 


\section{LATE MEDIEVAL AND EARLY MODERN DEMONOLOGY}

The change in tone and focus of late medieval demonology allowed for a greater focus on the physical nature of demons, witchcraft, and the witches themselves. This led to the utilization of strip searches and physical examinations to prove diabolic activity in court proceedings. Demonology provided the blueprint for understanding the physical nature of witchcraft. In the Middle Ages, the term demonology was used to describe the systematic and logical study and classification of Satan and his demons. Demonologists focused on determining the physical, mental, and spiritual capabilities of demons and how they could influence humans and the natural world. Demonology was a specific subset of theology, and as such, was studied by a small group of people. Academic demonology did not necessarily coincide with common, or popular, witchcraft belief. While the intellectual, or elite, interest in witchcraft was based on scripture and a strong theological foundation, popular witchcraft belief was constructed around folk lore and superstition. As the centuries progressed, demonology began to move from the realm of strictly theological to a much more publicized and popularized field. Demonologists became more active in and influenced by popular belief. With the reinforcement of confessions from an increasing number of witch trials, demonologists utilized a speculative approach entrenched firmly in examples and confessions from trials. These

confessions, which were often gathered by the demonologists themselves in their jobs as inquisitors, answered the demonologists' greatest questions regarding what the witches 
did, where they would meet their demonic patrons, and what they would do with the demons. While these confessions were most likely encouraged by the use of leading questions by the inquisitors, the impact on demonology was immediate. The change in tone and focus of late medieval demonology allowed for a greater focus on the physical nature of demons, witchcraft, and the witches themselves. This change in tone led to the search for physical proof of witchcraft, the utilization of strip searches, and physical examinations to prove diabolic activity in court proceedings.

Early theologians such as Bernard Gui and Nicholas Eymerich were not as active in the witch trials as later demonologists such as Nicolas Rémy, Jean Bodin, and Peter Binsfeld. Therefore, their sources were either secondary stories or conjecture. Once inquisitors and non-theologians became more seriously engaged in the scholarly discussion surrounding the activities of witches and demons, the focus of debate and the source material changed. Those who were actively involved in witch trials had new primary sources to utilize in their research in the form of trial testimony. Matthew Hopkins, for example, was far removed from the theological world, but still managed to force himself into the world of demonology. As the self-proclaimed Witchfinder General of England, Hopkins put nearly 300 women on trial for witchcraft in East Anglia alone in the 1640 s, resulting in the death of approximately one hundred of them. ${ }^{48} \mathrm{He}$ was involved solely in witch trials, where he was able to reinforce his prior demonological beliefs with testimony coerced from the accused. Both Bodin and Rémy were active participants in the trials and interrogations of numerous accused witches. These interrogations, where witches confessed to numerous activities, including maleficium,

\footnotetext{
${ }^{48}$ Malcolm Gaskill, "Witchcraft and Evidence in Early Modern England," Past \& Present 198 (February 2008), 49.
} 
murdering babies, and riotous sabbaths with demons, were the key sources for demonologists. They would ask very specific, and almost certainly leading, questions of the accused and wait until they heard the answer that would confirm their beliefs. Heinrich Kramer, the main author of the Malleus Maleficarum, one of the most influential witchcraft and demonological treaties of the fifteenth century, confirmed that most suppositions were based on testimony from accused witches. He wrote, "But the theory that modern witches are tainted with this sort of diabolic filthiness is not substantiated only in our opinion, since the expert testimony of the witches themselves has made all these things credible. ${ }^{49}$ Most likely, this so-called expert testimony was given by women who were willing to agree with whatever idea the interrogator placed in front of them in order to end the interrogation.

Before later demonologists merged demonology with the study of witches, the perception regarding the power of demons and their abundance was much different. The famous fourteenth-century Inquisitor Bernard Gui in his Practica officii Inquisitionis heretice pravitatis was more concerned with proper Inquisitorial procedure than he was with demonic witchcraft. His work provided a guide to Inquisitors on how to conduct interrogations for members of multiple heresies as well as those who practiced magic. The diabolic aspect of witchcraft, and the supposed maleficium (or bad deeds) that the witches practiced, were not a main concern.

Similarly, another fourteenth century demonologist, Nicolas Eymerich, was only focused on individual practitioners of ceremonial magic that summoned demons to do the

\footnotetext{
${ }^{49}$ Heinrich Kramer and James Sprenger, The Malleus Maleficarum, trans. Rev. Montague Summers (New York: Dover Publications, Inc., 1971), 111.
} 
sorcerer's bidding. ${ }^{50}$ This belief was due to a completely different view regarding who the primary people involved in such behaviors were. For early demonologists like Gui and Eymerich, sorcery was an intellectual pursuit, typically practiced by those wealthy enough to be literate and to afford books of spells so that they could summon demons themselves. Due to the prerequisite of literacy, sorcerers were typically male. Women were much less likely to possess the wealth and the literacy necessary to be considered sorcerers. After the shift in attitude of demonologists who began to view magic as a demonically inspired activity instead of an intellectual pursuit, sorcery changed to witchcraft, and women became more suspect than men for multiple reasons. Most importantly, women were believed to be more easily seduced or tricked than men, as evidenced in the Malleus Maleficarum and the Compendium Maleficarum. This, according to demonologists and theologians, was a biological and medical fact. European culture saw women's bodies as secretive, especially with regard to sexuality and reproduction. ${ }^{51}$ This secrecy made it easy to speculate. The medieval reliance on humoral theory meant everything in medicine ultimately was divided by the four humors- black bile, yellow bile, phlegm, and blood- and by the four elements that made up mankind: cold, moist, warm, and dry. This meant that women, who were viewed as being cold and moist (as opposed to the male composition of warm and dry), were physically inferior to men. As Kramer wrote in the Malleus Maleficarum, "since [women] are feebler both in mind and body, it is not surprising that they should come more under the spell of

\footnotetext{
${ }^{50}$ Norman Cohn, Europe's Inner Demons: The Demonization of Christians in Medieval Christendom, Revised Edition (Chicago: The University of Chicago Press, 1993), 78.

${ }^{51}$ Julia M. Garrett, "Witchcraft and Sexual Knowledge in Early Modern England," Journal for Early Modern Cultural Studies 13, 1 (Winter 2013), 39.
} 
witchcraft." ${ }^{, 52}$ According to medical opinion, women's minds were weaker and their reasoning skills were less developed. Therefore, if a woman were to meet a demon, or even Satan himself, she would be unable to recognize the danger she was in. Again, Kramer wrote in the Malleus that women are "the more credulous; and since the chief aim of the devil is to corrupt faith, therefore he rather attacks them." ${ }^{, 53}$ So according to demonological belief, women were easier for demons to trick into using witchcraft because of their inferior physical composition and their gender.

According to long-standing Christian tradition, female virginity was of vast importance. ${ }^{54} \mathrm{~A}$ demon, however, could offer women physical pleasure, and the woman could be tricked and swayed towards evil. Witches were the inversion of a proper Christian woman even when it came to their sexual practices. Here again, the demonologist was focused on the physical nature of the act of witchcraft, both in the case of the demon, who must appear in corporeal form to seduce the woman, and in the case of the woman, who readily accepted physical pleasure or gain in exchange for her soul. According to demonologists, demons would easily prey on women, which led to the idea that women would continually engage in sexual behavior with demons at their sabbaths. Kramer noted in the Malleus that "[witches burned in the German city of Ratisbon] all agreed in this, namely, that they were bound to indulge in these lewd practices in order that the ranks of their perfidy might be increased." ${ }^{, 55}$ This behavior broke traditional societal gender expectations regarding women. Women who were libidinous, like

\footnotetext{
${ }^{52}$ Kramer and Sprenger, The Malleus Maleficarum, trans. Rev. Montague Summers, 44.

${ }^{53}$ Ibid., 43.

${ }^{54}$ Sandy Bardsley, Women's Roles in the Middle Ages (Westport, Connecticut: Greenwood Press, 2007), 29.

${ }^{55}$ Ibid., 111
} 
witches, were dangerous to society. Men were concerned about female sexuality for multiple reasons, one of the most obvious being the risk of infidelity within marriage. If a woman conceived a child through adultery, it would bring shame to both her husband's and her father's houses. Heinrich Kramer echoed the sentiments of all other demonologists when he wrote that, "the word woman is used to mean the lust of the flesh. ${ }^{, 56}$ Women were responsible for upholding the respect and honor of both families, and any infidelity could bring ruin to the men in her family.

The debate about whether demons could procreate with humans was of great concern and interest for late medieval demonologists. Once the demonologist had weighed in on the debate surrounding the physical nature of the demonic body, they had to determine what the demon was capable of in its new corporeal form. Most demonologists believed that demons would have intercourse with both men and women, taking the form of the opposite sex to seduce the human. These demons were known as incubi (male demons) and succubi (female demons). It became standard belief that demons would take the form of a succubus, seduce a man, steal their semen, transform into an incubus, and seduce a woman. ${ }^{57}$ From these encounters, it was believed that demons could impregnate a human woman. According to Francesco Maria Guazzo, in his Compendium Maleficarum, "Almost all the Theologians and learned Philosophers are agreed, and it has been the experience of all times and all nations, that witches practise coition with demons, the men with Succubus devils and the women with Incubus devils... This truth can be proved by argument. For demons can assume the bodies of

\footnotetext{
${ }^{56}$ Kramer and Sprenger, The Malleus Maleficarum, trans. Rev. Montague Summers., 43.

${ }^{57}$ Michael D. Bailey, Magic and Superstition in Europe: A Concise History from Antiquity to the Present (Lanham, MD: Rowman \& Littlefield Publishers, Inc., 2007), 99.
} 
dead men, or make for themselves out of air a palpable body like that of flesh, and to these they can impart motion and heat at their will." ${ }^{, 58}$ While the result of this union between an incubus and a human woman would not be a half-demonic child, since according to texts like the Malleus, the semen used to create the child was obtained from a human man and remained human, the societal impact would be disastrous. If women were getting pregnant with children by random men in the community, then the social order would be disrupted. Paternity of children could easily be called into question, inheritances could be given to the wrong children, and women could become pregnant with children out of wedlock. Again, the physical impact of the demon is the obvious focus of the demonologists, with the creation of a human child the most concrete proof of their effects on earth.

Not only was it believed that demons could impregnate women, but it was also a popular belief in demonological texts that witches and demons could steal men's penises. ${ }^{59}$ Stolen penises demonstrated how disastrously demons could trick human beings and how thoroughly they could convince mankind of altered versions of reality. ${ }^{60}$ Certainly, this represents one of the greatest examples of the fear of the physical nature of demons outside of demonic possession. In the Malleus Maleficarum, Heinrich Kramer devoted a great deal of text to the very possibility. Kramer and many other leading demonologists of the time believed that witches, imbued with the power of Satan or a demon, could either physically steal a man's penis or could magically deceive the man

\footnotetext{
${ }^{58}$ Francesco Maria Guazzo, Compendium Maleficarum: The Montague Summers Edition, trans. E. A. Ashwin (New York: Dover Publications, Inc., 1988), 30.

${ }^{59}$ Walter Stephens, Demon Lovers: Witchcraft, Sex, and the Crisis of Belief (Chicago and London: The University of Chicago Press, 2002), 301-302.

${ }^{60}$ Ibid., 302.
} 
into believing his penis had been stolen. ${ }^{61}$ It was believed that witches could perform praestigium (illusionary magic specific to demonic magic) to convince men of the theft. ${ }^{62}$ In fact, this form of praestigium, which was able to convince humans of altered realities, was used by many demonologists as proof that demons were in fact made by God and were not the imagination of humans. ${ }^{63}$ This was another physical proof of the supernatural.

In a society where reproduction was of the utmost importance, the possibility that a demon or witch could steal the possibility to procreate from a man was certainly panic inducing. Without the ability to produce heirs, society as it was known would cease to exist. The subject of penis stealing, and its explanations by Heinrich Kramer in particular, is one of the most important subjects in witchcraft theory. It not only details a very troubling aspect of witchcraft for men in the late medieval and early modern periods, but the theory surrounding how witches are capable of performing such an act as penis stealing is applicable to the theory of witchcraft as a whole: namely, that witches were using their demonically obtained powers to affect the most important aspects of the physical world. Whether those effects were reality or a trick, the danger for the community was the same.

Another very important aspect of demonology was the realm of possession. There are two types of spiritual possession, divine possession and demonic possession. These two opposing states both corresponded to cultural categories constructed around exterior

\footnotetext{
${ }^{61}$ Stephens, Demon Lovers, 302.

${ }^{62}$ Ibid., 303.

${ }^{63}$ Ibid., 303.
} 
behaviors. ${ }^{64}$ Either someone could be possessed by the Holy Spirit and be compelled to do miracles and behave in a way concordant with the very presence of God being within them, or they could be possessed by a demon and exhibit the exact opposite behaviorsones that manifested the personally and socially destructive consequences of demonic influence. Both manifest themselves in a very physical way. Demonic possession, that is the belief that a demonic spirit could enter the body of a man or woman and control them both physically and mentally, was uncommon in late medieval and early modern Europe. Possession was complete demonic control over a person's body, but generally not their soul. ${ }^{65}$ This is proof of the importance placed on the physical body by demonologists, who insisted the soul of the demoniac, or possessed person, could be saved with an exorcism. With cases of possession, the physical body was viewed as the obvious proof of the supernatural, similar to physical evidence used in witch trials that were used to prove the supernatural as well.

The symptoms of possession are almost entirely physical. These symptoms include, but are not limited to, physical convulsions, extra-ordinary facial or bodily contortions, levitation, exceptional strength, and speaking in altered voices, particularly female demoniacs speaking in masculine demonic voices. Other symptoms are not visible, but equally affect the physical presentation of the possessed such as speaking in previously unknown foreign languages, babbling meaningless phrases, and impenetrable silence. ${ }^{66}$ The Compendium Maleficarum by Guazzo lists over fifty physical signs of

\footnotetext{
${ }^{64}$ Nancy Caciola, Discerning Spirits: Divine and Demonic Possession in the Middle Ages (Ithaca and London: Cornell University Press, 2003), 32.

${ }^{65}$ Sarah Ferber, Demonic Possession and Exorcism in Early Modern France (London and New York: Routledge, 2004), 25.

${ }^{66}$ Ibid., 26.
} 
possession.$^{67}$ Before an exorcism was done, often something called a probative exorcism was conducted to determine what spirit was inhabiting the victim. ${ }^{68}$ These probative exorcisms were entirely focused on studying the physical comportment of the perceiveddemoniac. If any of the physical symptoms listed above were present, then often a proper exorcism would follow closely behind. Exorcisms were required to prove the reality of possession. ${ }^{69}$ Tests to prove possession or witchcraft were important pieces of physical evidence to prove the existence of the supernatural.

During the early Middle Ages, theologians were focused on understanding the nature and beliefs of heresy and specific doctrinal beliefs. Medieval demonologists were much less concerned with doctrine and more so concerned with the physical reality of demons, and in turn, witches. The debate was continually raised about whether demons could take on a physical, corporeal form, and if so, what they could do with said form. The debate about whether demons could procreate with humans was of great concern and interest for the majority of late medieval demonologists. If witches engaged in acts of depravity with demons, as was heartily asserted, then demonologists wanted to know exactly how and when it would occur. Understandably, this then led to questions about the true nature of a witches' sabbath, with demonologists such as Heinrich Kramer constantly striving to understand its nature. ${ }^{70}$ Not only did the demonologists desire to know what activities the witches and demons engaged in at the sabbaths, but they also were particularly concerned with whether the witches were even physically present at the sabbaths. There were two theories: either the witches physically flew to the sabbaths and

\footnotetext{
${ }^{67}$ Francesco Maria Guazzo, Compendium Maleficarum: The Montague Summers Edition, 167-169.

${ }^{68}$ Ferber, Demonic Possession and Exorcism in Early Modern France, 24.

${ }^{69} \mathrm{Ibid} ., 26$.

${ }^{70}$ See Part II, Question I, Chapter III of The Malleus Maleficarum.
} 
were present in body and spirit, or the witches would spiritually or mentally travel to the sabbath while their physical body remained in place. As Heinrich Kramer wrote, "the devil knows the thoughts of our hearts; how he can substantially and disastrously metamorphose bodies with the help of an agent; how he can move bodies locally, and alter the outward and inner feelings to every conceivable extent; and how he can change the intellect and will of a man, however indirectly.",71 According to Kramer, Satan has the ability, with the help of his servants, to move bodies and change their shapes. This type of assertion lent itself to the idea that witches physically flew to sabbaths and performed physical acts while there.

Heinrich Kramer, the best known demonologist of the fifteenth century, and author of the Malleus Maleficarum, was keenly focused on the physical nature of witches and how the witch interacted with the physical world around them. Like demonologists before him, Kramer relied on scripture and towering medieval theologians such as Augustine and Aquinas to argue his beliefs. Unlike earlier demonologists, however, he also relied heavily on anecdotes, conjecture, and hearsay. Kramer focused most of his work on the sexual nature of witches and demons. The Malleus included a plethora of suppositions regarding how women and demons interacted, and why almost all witches were women. Kramer even detailed whether demons were capable of taking a physical form, what that physical form would look like, and how that physical form compared to the human form. Kramer believed that demonic bodies were inferior to those of humans particularly because they could not properly speak. According to Kramer, "Devils have no lungs or tongue, though they can show the latter, as well as teeth and lips, artificially

\footnotetext{
${ }^{71}$ Kramer and Sprenger, The Malleus Maleficarum, trans. Rev. Montague Summers, 23.
} 
made according to the condition of their body; therefore, they cannot truly and properly speak." 72 Similar to his arguments about penis stealing, Kramer returned to the concept of deception and illusion- while demons were incapable of truly speaking, they were able to appear as if they could. The importance of the illusion was not lost on Kramer and other fifteenth-century demonologists. Kramer's focus on the physical nature of demons and the importance of their physical reality became incredibly important for all demonologists who followed him.

Sixteenth-century demonologists were much less concerned with specific doctrine and more so concerned with the physical reality of demons, and in turn, witches. Most likely this followed after the success that greeted Heinrich Kramer's Malleus Maleficarum in the fifteenth century. The debate was continually raised about whether demons could take on a physical, corporeal form, and if so, what they could do with said form. In Nicolas Rémy's Demonolatry, the nature of a demon's physicality is central to the argument of the treatise. For example, Rémy stated that, "Demons are by nature incorporeal (Psalm civ, 4; and Hebrews i. 7); but it was agreed even by the Platonists that they can for a time assume and make use of a body condensed out of the air or from some grosser matter; and S. Augustine, in his De Natura Daemonum, does not deny that he is of the same opinion. ${ }^{, 73}$ What the body consisted of was debated, and ultimately depended on the choice of the demon adopting the body. Rémy and others concluded the body could be made of air, earth, or fire. The only element not available to demons was water, as it was believed to be God's purest element. ${ }^{74}$ Since these demons were made of base

\footnotetext{
${ }^{72}$ Kramer and Sprenger, The Malleus Maleficarum, trans. Rev. Montague Summers, 110.

${ }^{73}$ Nicolas Rémy, Demonolatry, trans. E. A. Ashwin (New York: Barnes \& Noble Inc., 1970), 27.

${ }^{74}$ Heikki Pihlajamäki, "'Swimming the Witch, Pricking for the Devil's Mark': Ordeals in the Early Modern Witchcraft Trials," 36.
} 
elements or were inhabiting dead bodies, they never looked entirely human, and often were associated with a foul stench and unwillingness to bathe, again because of the purity of water. Rémy stated that the Devil "takes immoderate delight in external filth and uncleanness. For often he makes his abode in dead bodies; and if he occupies a living body, or even if he forms himself a body out of the air or a condensation of vapours, his presence therein is always betrayed by some notably foul and noisome stench ... and so the Devil for the most part has for his servants filthy old hags whose age and poverty serve but to enhance their foulness; and these, as being of a vitiated nature most apt to his purpose, he instructs in all impurity and uncleanness. ${ }^{, 75}$ For Rémy, the dirtiness of the demons is shown both by the dirtiness of their assumed physical forms and by the physical appearance of those that the demons chose to serve them.

Incredible detail was paid to the exact appearance of demons and demonic familiars in these demonological treaties. Rémy described to his readers the typical appearances that demons would take, and argued that, luckily, demons were always easily spotted. Rémy wrote that "Demons can never so completely ape the human shape but that the deception is apparent to even the most stupid. Either their countenance is of a hideous foulness; or their hands and feet are distorted and hooked with claws like those of obscene vultures; or else they are conspicuous by reason of some evident mark which betrays the savageness of their nature." ${ }^{, 76}$ While this mark on the body of a demon is easily visible, the mark of foulness is also believed to be evident on the witch as well. Just as a demon's physical appearance is described by demonologists, so too is a witch's

\footnotetext{
${ }^{75}$ Rémy, Demonolatry, trans. E. A. Ashwin, 38.

${ }^{76}$ Ibid., 28.
} 
appearance, which gave even more credence to the idea that physical proof on the body of a witch could be a sign of the supernatural.

Whether the possession or bewitchment of bodies was physical reality or elaborate illusion was a matter of discussion amongst theologians and demonologists. This question was not asked solely for understanding the nature of possession, but also for understanding what demons and devils, and to a lesser extent, witches, were physically capable of in the natural world. While demons were not physically possessing witches, they did grant witches their power, meaning witches and demons shared some physical abilities. All demonologists acknowledged the unparalleled ability of Satan and his demons to cast tricks of the mind and create confusion amongst humans, but a distinct difference was drawn between a demon's illusory powers and its physical powers on earth. Therefore, a majority of demonological treaties revolve around whether demons and witches imagined their powers or physically have them.

As Heinrich Kramer suggested, witches are the servants of Satan on earth because Satan does not possess the power necessary to impact the physical world himself. In the Malleus, Kramer often discussed demons in the same sentence as witches. They remain separate entities, with separate powers, but witches cannot exist without demons, and demons have more power in the world with witches working for them. For Kramer, the two operated hand in hand. Kramer wrote that, "the devil cannot so easily and readily do harm by himself to mankind, as he can harm them through the instrumentality of witches, although they are his servants." ${ }^{, 77}$ Satan was only capable of deceit, illusions, and lies; in

\footnotetext{
${ }^{77}$ Kramer and Sprenger, The Malleus Maleficarum, trans. Rev. Montague Summers, 12.
} 
other words, Satan was a trickster. ${ }^{78}$ To have true physical impact, he needed others to assist him. Thus, witches were required to have physical power to cause the chaos required by Satan. Whether they were truly flying to sabbaths or truly had the capability to transform men into animals, the witches still had the capability to both be influenced by demons and to influence the physical realm on their behalf. Maleficium, the most common form of magic practiced by witches, was solely focused on causing destruction in the physical world.

The study of medieval and early modern demonological belief is a key component in understanding both the shift in how witchcraft was viewed and the change in trial procedures. Without the elite theological belief in the physical nature of demons and how their physical body can interact with a witch's, the concept of physical markings on the bodies of witches would not have become as widespread in trials conducted by elites. Without a corporeal form, demons would not be able to mark witches, and without the assistance of demons, witches would have never had the physical ability to fly to sabbaths and engage in maleficium. Without the overwhelming concern about the physical nature of witches and demons, witch trials would have never included searches for witches' marks, and possibly would not have included such physical tests as the swimming test. An understanding of the shift in demonological thought in the late Middle Ages is key in understanding the medical and scientific tests utilized during later European witch trials.

\footnotetext{
${ }^{78}$ Fabián Alejandro Campagne, "Demonology at a Crossroads: The Visions of Ermine de Reims and the Image of the Devil on the Eve of the Great European Witch-Hunt," Church History 80, 3 (September 2011), 471.
} 


\section{MEDICAL EVIDENCE AND THE SEARCH FOR THE WITCHES' MARK}

Throughout the early modern period in Europe, trial records for accused witches and witchcraft texts include references to so-called witches' marks. According to contemporary texts, these were physical marks on witches clearly visible to the naked human eye. Doctors and midwives verified these marks upon examination of the accused witch's body. In this instance, science and religion worked together to provide incontrovertible proof of witchcraft. These marks were physical proof of witchcraft, and by extension, the supernatural. This physical proof was crucial for witch trials and for the propagation of witchcraft belief.

Comparable to the discussion of medical evidence in witchcraft trials is the use of medical evidence to prove the sanctity of possible saints. These so-called holy autopsies were used by the Church to prove with scientific accuracy that members of the flock were truly touched by God. Often their bodies would contain signs of their holy nature; a crucifix in the heart, rosary beads in the spleen, and even miraculous preservation of the body were seen as evidence of the divine. ${ }^{79}$ Likewise, scientific proof was also used in order to prove evidence for the unholy. The importance of medical evidence in both witch trials and holy autopsies proves the importance that scientific evidence had in early modern Europe. As anxiety surrounding religion grew amongst the nobility and lower

\footnotetext{
${ }^{79}$ Katharine Park, "The Criminal and the Saintly Body: Autopsy and Dissection in Renaissance Italy," Renaissance Quarterly 47, 1 (Spring 1994), 1-2.
} 
classes alike, due to various Protestant heresies becoming popular, evidence needed to be unquestionable.

There are multiple explanations for the so-called devil marks, depending on the time period, the geographical location, and even the gender of the accused witch. There is a particularly sharp difference between beliefs on the European continent and those in England and Scotland. Mainland witch beliefs were relatively similar throughout western Europe, even if they were interpreted slightly differently from country to country. Often the differences were due to the political and cultural tradition of the country applying them. The beliefs about devil marks also change over the centuries, starting as a small idea purported in folklore and becoming obvious proof of witchcraft.

The first, and more popular explanation for the witch's mark was related to the overall demonological idea that to become a witch, one had to enter into some sort of relationship with Satan. The devil mark was a consequence of this relationship. Earlier in the fourteenth and fifteenth centuries, these relationships were simple trades with Satan that would end in disappointment for the witch. Satan would come to meet a potential witch, disguised as either a trader or beggar, and offer the person something they wished for, often money or food. All the witch had to do was pledge their soul in return. After the deal was struck, whatever the witch got in return for their soul was changed to something less desirable; a precious metal chalice would turn back to wood, contents of the witch's cup previously full would be spilled, or delicious wine would be changed to blood ${ }^{80}$ As the centuries progressed and demonologists continued creating elaborate creation myths for witches, the relationship between the witch and Satan became much

\footnotetext{
${ }^{80}$ Fabián Alejandro Campagne, "Demonology at a Crossroads: The Visions of Ermine de Reims and the Image of the Devil on the Eve of the Great European Witch-Hunt," 471.
} 
more sexual. As evidenced in demonological texts such as the Compendium Maleficarum or the Malleus Maleficarum, witches would engage in sexual relationships with various demons and occasionally even Satan himself. Thus, the spot was a mark of the witch's bodily and spiritual servitude and indebtedness to Satan. Inquisitors and interrogators were continually searching for easier and more effective ways to identify witches, which led to the most widespread test, pricking for the devil's mark. The devil's mark was believed to be an insensible mark on the body made at the very moment the devil seduced the witch to the side of darkness. ${ }^{81}$ It was also thought to be the spot on the witch's body where the Devil's claws had raked the witch's skin. ${ }^{82}$ According to early modern demonologists and trial records, if a witch had a devil's mark, all that had to be done to find it was prick the witch with a pin until the examiners found a spot that, when pricked, did not bleed. ${ }^{83}$ Once this spot was found, the proof was evident that the woman was a witch and that the supernatural existed.

Another explanation, that was much more popular in England than on the continent, was the idea of a witches' teat. ${ }^{84}$ This teat, or nipple, was believed to be used by witches to suckle their animal or demonic familiars. ${ }^{85}$ These familiars, or imps as they are sometimes called, would assist the witch in her evildoings within the community. The search for a witches' teat was much less complicated than the search for a devil's mark. All an examiner had to do was find any sort of mark on the body that looked remotely

\footnotetext{
${ }^{81}$ Robin Briggs, "Dangerous Spirits: Shapeshifting, Apparitions, and Fantasy in Lorraine Witchcraft Trials," in Werewolves, Witches, and Wandering Spirits: Traditional Belief \& Folklore in Early Modern Europe, ed. Kathryn A. Edwards (Kirksville, MO: Truman State University Press, 2002), 3.

${ }^{82}$ Heikki Pihlajamäki, "'Swimming the Witch, Pricking for the Devil's Mark': Ordeals in the Early Modern Witchcraft Trials," 36

${ }^{83}$ Ibid., 36.

${ }^{84}$ Robin Briggs, "Dangerous Spirits," 3-4.

${ }^{85}$ Owen Davies, Witchcraft, Magic and Culture: 1736-1951 (Manchester and New York: Manchester University Press, 1999), 184.
} 
like a nipple and the proof was instant. The search for these so-called teats was quite a common practice. It most likely was a reference to the common theme of witches as bad mothers or women who abandoned the traditional female role of motherhood altogether. ${ }^{86}$ Female witches were consistently accused of an aversion or all-around inversion of the role of motherhood. Instead of nursing a human child with their nipples as women were supposed to do, witches would invert the trope of the good mother and grow an extra, diabolic, nipple to nurse animals or even demons.

Witches' teats could have been anything from skin tags, moles, warts, an actual third nipple, or even something that would be diagnosed today as a melanoma. Any unexpected or unexplained piece of skin on the body could have been passed off as a witches' teat. Unlike devil marks, these witches' teats were always believed to be visible, and were not considered a hidden or insensible spot on the body of the witch. The visibility of the mark made it that much more convenient for interrogators to find and use as proof. The judicial context in which the marks were found led to their new belief in the marks being demonic in origin, not a lack in intelligence or medical knowledge. The popularity in the belief in the witches' teat stemmed from the ease of observability of the teat itself.

Later in the eighteenth and nineteenth centuries, the popular belief in witches' teats rapidly declined. This most likely corresponded with the end of officially endorsed strip-searching of witches. ${ }^{87}$ Of course the belief in demonic nipples and evil marks declined after strip searches were made illegal, since the only way to spot them was to thoroughly search every inch of the witch's body in what must have been a very

\footnotetext{
${ }^{86}$ Briggs, "Dangerous Spirits," 3.

${ }^{87}$ Owen Davies, Witchcraft, Magic and Culture, 184.
} 
traumatic experience for those enduring it. When judicial strip searches were outlawed, the focus on bodily proof, in this instance, faded away. This means that the interest in witch's marks was so prevalent in the early modern period due to the allowance of judicial strip searches, which were simply outlets to provide statutory proof.

Many trial records are quite clear in regard to their inclusion of the search for the witches' marks. Particularly in England, the inclusion of the search for devil marks in the trial records is quite common in the sixteenth century. In the trial records for Annis Glascocke, an accused witch in late sixteenth century England, "Annys Letherdall and Margaret Sympson women appointed, to see and view the body of this Examinate: sayde, and affyrme upon their credites, that upon the left side of the thighe of this Examinate, there be some spots, and upon the left shoulder likewise one or two: Which spottes bee like the sucked spots, that [convicted witch] Ursley Kempe hath upon her bodie." 88 While no further reference to the sucked spots were made, Annis was convicted of witchcraft shortly after this revelation in the records.

Similarly, in the 1582 examination and confession of Henrie Selles and his wife Cysley, Cysley is the only one of the pair to be examined for devil marks, of which she apparently had multiple. As the trial records state, "Ales Gilney, Joan Smith, and Margaret Simson women of credite, appointed by mee Brian Darcey, to view and see the body of the saide Cysley, say, that shee hath upon her body many spots very suspitious, and the said Margaret saith, that they bee much like the sucked spots, that shee hath seene upon the body of Ursley Kempe." 89 The record was not only stating that Cysley had

\footnotetext{
${ }^{88}$ Marion Gibson, Early Modern Witches: Witchcraft Cases in Contemporary Writing (London and New York: Routledge, 2000), 94. Cited the trial record "A true and just Recorde" by W. W. from 1582.

${ }^{89}$ Ibid., 103.
} 
multiple spots on her body, but that they were also the same type of spot that was seen on the body of another previously convicted witch, thus demonstrating the importance of context in regards to the discovery of the marks. This compounding of proof, both the existence of a devil's mark and the supposed relation to the mark of another witch, made Cysley even easier to convict than most. Not only was she associated with the supernatural, but she was also now associated with another confirmed witch.

In another trial record, an accused witch was specifically charged with feeding her familiars. The record stated that during the trial proceedings, "[the judge] commanded [Mary Sutton] to be taken out, and had women readie that searched her, and found under her left thigh a kind of Teat, which after the Bastard sonne confest her Spirits in severall shapes as Cats, Moales, \&c. used to sucke her." 90 This account in particular shows the portrayal of the witch as a bad mother, and therefore a bad woman, since this witch's own bastard son confessed that she fed her familiars from her extra nipples. This also is evidence of the importance of eyewitness testimony and character witnesses.

Another trial record went into even more detail about the teats. In the 1653 trial of Anne Bodenham, a panel of women who searched her body testified that Anne had, "the marks of an absolute Witch, having a Teat about the length and bignesse of the Nipple of a womans breast, and hollow and soft as a Nipple, with a hole on the top of it, on her left shoulder, and another likewise was found in her secret places, like the former on her shoulder." 91 This description, certainly one of the most detailed, emphasized the fact that

\footnotetext{
${ }^{90}$ Witches Apprehended, 1613, in Early Modern Witches: Witchcraft Cases in Contemporary Writing, Marion Gibson, (London and New York: Routledge, 2000), 275.

${ }^{91}$ Orna Alyagon Darr, Marks of an Absolute Witch: Evidentiary Dilemmas in Early Modern England, Orna Alyagon Darr (Burlington, VT: Ashgate Publishing Company, 2011), 111. Cited the trial record "Doctor Lambs Darling" from 1653.
} 
these witches' teats were actual, functioning nipples, again emphasizing the relationship between female witches and motherhood. According to the jury and court, Anne had developed an actual third nipple, which was implied in the record to be a fully formed and functioning nipple, with which to feed her familiars.

Devil marks were not the only physical signs of a witch. Later, in the seventeenth century and beyond, witches were believed to be physically ugly because of their diabolic nature. This idea is certainly a reflection of the medieval and Renaissance beliefs about the outer physical appearance of a person's body matching their inner goodness. The modern notion of witches being ugly hags certainly comes from this concept, and it could be argued that the notion of witches always being portrayed as having warts could be a correlation to the devil mark. An early seventeenth-century example is that of Elizabeth Device, whose daughter was forced to testify against her at the age of nine. Prior to Elizabeth's daughter's testimony, Elizabeth's physical appearance was heavily scrutinized for any signs of evil or demonic relationships. The court concluded that Elizabeth's apparently unappealing physical appearance was a sign that nature itself placed upon her as an indication and forewarning of her wrongdoings. The records state that, "This odious Witch was branded with a preposterous marke in Nature, even from her birth, which was her left eye, standing lower then the other; the one looking downe, the other looking up, so strangely deformed, as the best that were present in that Honorable assembly, and great Audience, did affirme, they had not often seene the like. ${ }^{.92}$ In this instance, although there is no direct reference to a specific mark or teat, Elizabeth's presumably lazy eye is called as medical and physical proof of her

\footnotetext{
${ }^{92}$ Thomas Potts, The Wonderfull Discoverie of Witches, 1612, in Early Modern Witches: Witchcraft Cases in Contemporary Writing, 202.
} 
debauchery. Not only is the evidence readily visible on the body, as all other witches' marks were, but here even the audience and legislators agreed upon the odd nature of her visage. It was no coincidence that the records mentioned the audience's reaction to Elizabeth's face, it served as proof and, in part, testimony to the present facts of the case.

The verification of the physical deformity was just as important as the presence of the deformity for a witch trial. After all, the physical presence of these witches' marks was the primary appeal of them; anyone viewing the body of an accused witch could easily recognize the mark and thus prove the diabolic nature of the person. The important aspect of such physical proof was that it would always exist and that it was there to be shown to others. No longer did witch trials have to rely upon the accounts of others about the accused's maleficium; it could just be shown to the judge in person. Similar to probative exorcisms, there were certain key signs an investigator would look for when searching the body of a witch. A devil mark would prove the accused was a witch so that a further inquest could be done before sentencing. Once the accused was discovered to possess the mark, the demonologists and witch hunters could ask their leading questions to confirm aspects of witches' sabbaths that they already had decided upon prior to any interrogations.

As can be seen in the examples shown previously, women were primarily the ones tasked with searching for the witches' marks. Since women inherently knew their own anatomy better than any man, it was left to them to search for any abnormality they could find on the female witch's body. The women who were charged with this search were chosen for their prominence in the community, their relationships with the accused, and their moral goodness, which was evaluated, of course, by male lawyers, as seen in the 
description of female assistants in the trial of Cysley Selles. ${ }^{93}$ The women had to be the most trusted in the community in order for them not to later be accused of witchcraft themselves if they did not find any physical proof of witchcraft on the accused, lest they be accused for favoring the witch or purposely not reporting a spot or mark.

While women were the primary targets of witchcraft accusations, and by default this study, men also were accused of witchcraft, albeit much less often. Most of the men who were accused were associated either through blood or close relationship with previously accused female witches. These male witches were typically charged with a different type of witchcraft than that of their female counterparts. The men would most commonly be accused of harming masculine objects such as horses and crop fields, not babies or bread like women, and were very rarely accused of flying or making subtly sexual pacts with Satan. ${ }^{94}$ Even though male witchcraft typically did not have many of the same overt references to Satan and his minions, these male witches were still searched for devil's marks. It was seen by the officials at the time that men, when accused of witchcraft, were just as likely to have a devil's mark on their body as the female witches. $^{95}$

So, if these devil's marks were not solely found on women, and were not a singular representation of the sexual relationship between a female witch and Satan or a demon, then they are clearly indicative of something else entirely. These marks had nothing to do with their purported function, and had everything to do with the physical

\footnotetext{
${ }^{93}$ Marion Gibson, Early Modern Witches, 103. Cited the trial record by W.W., "A true and just Recorde." ${ }^{94}$ Merry Wiesner, "Witchcraft," Women and Gender in Early Modern Europe (Cambridge: Cambridge University Press, 2000), 233-234, quoted in Lara Apps and Andrew Gow, Male witches in early modern Europe (Manchester and New York: Manchester and University Press, 2003), 32.

${ }^{95}$ William Monter, "Toads and Eucharists: The male witches of Normandy, 1564-1660," French Historical Studies 20, 4 (1997), 588.
} 
nature of the supposed proof. The name alone suggests the purpose - a mark from the devil himself. If a human being, regardless of gender, was found to possess one of these marks, then that meant that they were in league with or possessed by Satan. If a devil's mark was found on the body of an accused witch, it meant they were almost instantly found guilty. There was no testimony that could trump the physical proof that the judges could see in front of them and with their own eyes.

The witches' marks were not the only physical attributes of witchcraft. Many of the purported abilities of a witch were physical in nature as well. Witches flew to their sabbaths, conjured curses to afflict others, attacked farm animals, and could even defy laws of nature. The debate over how witches traveled to their sabbaths was a very popular focal point of witch hunters and theologians alike. Whether witches physically flew to their sabbaths was very important. Heinrich Kramer was not the only demonologist concerned with the way witches traveled to their sabbaths. Ulrich Molitor (d. 1507) wrote an influential treaty on the subject titled De Lamiis et Phitonicis mulieribus. ${ }^{96}$ In this treaty, Molitor gave examples of witches flying, riding wolves and dogs, and otherwise travelling to sabbaths. ${ }^{97}$ Molitor, however, was not entirely convinced that this was true, and is considered by most historians to be a moderate on the subject of witcheraft. ${ }^{98}$ Particularly in comparison with Kramer, Molitor's more skeptical tone balanced out the debate regarding witches' sabbaths.

Either witches physically flew to the woods to commune with devils or they simply imagined they did. Whichever side a demonologist chose, the physical nature of

\footnotetext{
${ }^{96}$ Jane P. Davidson and Bob Canino, "Wolves, Witches, and Werewolves: Lycanthropy and Witchcraft from 1423 to 1700," Journal of the Fantastic in the Arts 2, 4 (1990), 48.

${ }^{97}$ Ibid., 50.

${ }^{98}$ Ibid., 52.
} 
the sabbath, and in turn, witchcraft, was the key focus. All of these aspects of witchcraft were physical, making witchcraft a physical pursuit. For an act as physical as witchcraft, it stands to reason that there would be some sort of physical sign on their body to indicate their control over the physical world.

Another popular test to determine whether someone was a witch was called the dunking test or the swimming test. Swimming a witch, or ducking, was a test in which the accused had their wrists tied to their ankles, were thrown into water attached to ropes, and were observed to see if they sank or floated. If they sank, it meant the accused was innocent, because as God's purest element, water would not allow anything demonic to become submerged within it. If they floated, however, it meant that the water rejected them as a clear sign of their diabolic nature. ${ }^{99}$ This test was well documented and written about by many demonologists of the early modern era. Three of the earliest and most significant of these were Reginald Scot's Discouerie of Witchcraft, King James I's Daemonologie, and William Perkins' A Discourse of the Damned Art of Witchcraft. ${ }^{100}$ The verifiable and physical nature of the test was the most important aspect of it; anyone could watch the test and verify the accuracy, and in a way, it was a scientific test. The variables would always remain the same; the only difference from test to test was the witch that was being tested.

Witchcraft, at its very core, is a physical act. The type of witchcraft most commonly put on trial, maleficium, is physical. There is no conjuring of spirits, no calling upon great unknowns for intangible gifts; maleficium concerned itself with causing harm

\footnotetext{
${ }^{99}$ Heikki Pihlajamäki, "'Swimming the Witch, Pricking for the Devil's Mark': Ordeals in the Early Modern Witchcraft Trials," 36.

${ }^{100}$ Orna Alyagon Darr, Marks of an Absolute Witch: Evidentiary Dilemmas in Early Modern England (Burlington, VT: Ashgate Publishing Company, 2011), 159.
} 
and trauma to the physical world. Typically, those who were accused of practicing maleficium were also accused of trying to cause poor crop yields at harvest time, striking down an enemy's cow or pig, causing infertility, conjuring lightning or hail, and of using their witchcraft to cause physical pain or affliction to an enemy. ${ }^{101}$ All of these acts at their core are an attempt by a witch to affect the natural world, to affect something tangible. It stands to reason that, at least for early modern people, someone who affects the physical world would also have physical deformities or marks upon them from the power controlling them. Witchcraft, then, is entirely concerned with the physical proof of both the act and the demonic power given to the witch.

That is not to say, however, that everyone in the early modern era believed witchcraft was a physical manifestation of the power and diabolic evil of Satan. On the contrary, some theologians and witchcraft experts even believed witchcraft was not real, or at least not a physical reality like others purported. Again, Friedrich Spee was an advocate for the disbelief in physical witchcraft, and even in most cases, of witchcraft itself. Contained within his Cautio Criminalis, Spee explained his views on witchcraft. He wrote,

It is incredible what superstitions, jealousies, lies, slurs, mutterings, and the like there are among the common people in Germany, particularly (it is embarrassing to say) among Catholics, which the authorities do not punish nor preachers reproach, and which first arouse the suspicion of magic. All divine punishments which God threatens in the Holy Scriptures are committed by witches. God no longer does anything, nor nature, but everything is done by witches. Thus everyone shouts with great passion that the authorities should therefore investigate the witches of which they themselves created so many with their own tongues. 102

\footnotetext{
${ }^{101}$ Michael D. Bailey, Battling Demons: Witchcraft, Heresy, and Reform in the Late Middle Ages (University Park, Pennsylvania: The Pennsylvania State University Press, 2003), 29.

${ }^{102}$ Friedrich Spee von Langenfield, Cautio Criminalis, in The Witchcraft Sourcebook, ed. Brian P. Levack, 146.
} 
Spee's sixteenth-century sarcasm is clear: even if witches do exist, humans are the ones making the majority of them out of innocent people with accusations based on jealousy, rumors, and superstition. In fact, Spee's argument is even clearer in regard to the panic concerning the increased number of witches in the world. According to him, ascribing every unfortunate incident to witches takes agency away from nature, and even God.

Spee's argument is rebutted, obviously not directly, by Heinrich Kramer and James Sprenger's fifteenth-century Malleus Maleficarum. The first Question in the Malleus Maleficarum clearly states that witchcraft proves the existence of Satan and demons. ${ }^{103}$ Kramer and Sprenger wrote that, "Because the authority of the Holy Scriptures says that devils have power over the bodies and over the minds of men, when God allows them to exercise this power, as is plain from the very many passages in the Holy Scriptures. Therefore those err who say that there is no such thing as witcheraft, but that it is purely imaginary, even although they do not believe that devils exist except in the imagination of the ignorant and vulgar, and the natural accidents which happen to a man he wrongly attributes to some supposed devil." ${ }^{\text {104 }}$ According to Kramer and Sprenger, witchcraft is a physical reality in the natural world. In fact, Kramer and Sprenger offer a different view of God's role in witchcraft. For them, the very fact that there are so many witches by definition means that there must also be the tacit approval of God for all of the witches to exist and have power over the natural world. To believe otherwise in any way, according to Kramer and Sprenger later in their text, is heresy.

The lack of knowledge by male medical authorities regarding the female body meant that in order to find medical anomalies on women's bodies, women had to be the

\footnotetext{
${ }^{103}$ Walter Stephens, Demon Lovers, 47.

${ }^{104}$ Kramer and Sprenger, Malleus Maleficarum, trans. Rev. Montague Summers, 2.
} 
ones to search for them. Therefore, instead of having their bodies searched by the male doctors, accused female witches would be searched by midwives or other female authorities. This is perhaps most obvious in the trial account of Annis Glascocke, discussed more in depth previously, where the record makes clear that Annys Letherdall and Margaret Sympson were the two to search Annis' body. The account mentioned that they were in fact appointed by the court to serve as what can be termed as medical evaluators. They were chosen due to their trustworthiness and positive reputation to examine Annis' body. Similarly, in the trial of Cysley Selles, the judge, Brian Darcey, was proud to mention that he chose three "women of credite" to search Cysley's body. For 80-year-old Anne Bodenham, an entire group of well esteemed women were chosen to evaluate her, and in so doing found evidence of her suckling of imps and familiars. So medical knowledge was not necessarily a requirement in order to search for devil marks, but knowledge of female bodies was required.

Because of the physicality of the evidence provided by the searches for devil's marks, the evidence was deemed truthful and reliable. The emphasis is placed on the viewer; anyone who saw a woman be pricked with a pin and not bleed or a woman with a nipple on her shoulder would be ultimately convinced of both the guilt of the woman at stake and the reality of witchcraft. Not only would the danger of witchcraft be proven, but by the transitive property, so would the existence of the supernatural. The popularity of these medical proofs was not solely for their ease in prosecution or their permanent inscription upon a witch. These medical proofs did become more common due to their use as statutory evidence. ${ }^{105}$ The popularity was also because they were unquestionable

\footnotetext{
${ }^{105}$ Heikki Pihlajamäki, “'Swimming the Witch, Pricking for the Devil's Mark': Ordeals in the Early Modern Witchcraft Trials," 36.
} 
evidence of the existence of the supernatural. Physical proof, whether it be of witchcraft or even of sainthood, was the most persuasive evidence in early modern Europe.

While the search for witches' marks may seem like a small or insignificant aspect of witchcraft trial records, it in fact was one of the most important elements in any case, particularly in the scientific style of the procedural court system. ${ }^{106}$ Due to the physical and lasting nature of the marks, the witch was easily identifiable to the vulnerable public, which made it easier to catch them, try them, and eliminate the threat of them. Deep down, however, all of the tests to prove witchcraft, all of the importance of the physical nature of it, was for the proof of the supernatural.

\footnotetext{
${ }^{106}$ Heikki Pihlajamäki, “'Swimming the Witch, Pricking for the Devil's Mark': Ordeals in the Early Modern Witchcraft Trials," 36.
} 


\section{HOLY AUTOPSIES AND THE USE OF PHYSICAL EVIDENCE IN THE}

\section{CHURCH}

Until this chapter, this thesis has been concerned with witchcraft and demonology in the late medieval and Early Modern period in Europe, with particular emphasis placed upon physical evidence used to prove the existence of such diabolic beliefs. This final chapter will switch focus from the diabolic to the holy in order to prove the importance people of this time period placed upon tangible evidence. Mostly it will focus on holy autopsies, which were attempts to prove the deceased was saintly, and how the physical evidence found in these autopsies was utilized in a similar manner to the physical evidence found during witch trials to prove the existence of the supernatural. By demonstrating the value given to physical proof of sanctity in the late medieval and early modern period, this chapter reinforces the importance given to physical evidence of the demonic pact discussed in the previous chapter.

Many eighteenth and nineteenth century historians would characterize the late medieval and early modern periods as times of aversion towards the scientific study of the body after death. With laws in multiple countries against body snatching, stories of clandestine meetings to steal freshly buried dead bodies, and vastly popular anatomical dissections, it makes sense that people would come to that conclusion. Past historians have also characterized the early modern period in such a way, asserting that early 
modern people were either afraid of opening the human body or incapable of understanding it once it was open.

On the contrary; as has been shown earlier in this thesis, the people of the late medieval and early modern periods were heavily reliant upon the evidence that the study of the physical body could provide. Anxieties of the present should not be read back into the past. While there was clearly a heavy investment in funerary rituals, the investment did not extend to the integrity and impermeability of the corpse. ${ }^{107}$ It is important in this chapter, then, to keep the idea of an autopsy or dissection separate from the idea of violating funerary rites. This chapter will detail the ways in which autopsy and dissection were viewed in the early modern period, focusing mainly on the aspects of proving sanctity, and the supernatural, in women with so-called holy autopsies. Women's relationship with medicine and autopsies as a whole will also be detailed in order to show the relationship women had to the physical body.

This relationship with medicine and the opening of the physical body aligns with the importance of physical evidence used in witch trials. Physical proof was given the same importance in holy autopsies as it was in witch trials. Whether the body was studied in holy autopsies or in courtrooms, the result was the same- the physical nature and impermeability of the so-called proof was enough to provide undeniable evidence of either the holy or the demonic.

It is first important to define the terms that will be used throughout this chapter. The terms autopsy and dissection denote very different concepts. Autopsies refer to a post-mortem investigation into the cause of death for a person. Autopsies were most often

\footnotetext{
${ }^{107}$ Katharine Park, "The Criminal and the Saintly Body: Autopsy and Dissection in Renaissance Italy," 2122.
} 
conducted to determine if the deceased died of natural causes or was in fact murdered. ${ }^{108}$ An autopsy was done solely to find the cause of death, with no educational aspect. In fact, autopsies were typically private, with no students viewing the affair.

A dissection, on the other hand, was done for academic purposes. There was no search for a cause of death, and there was no limit to what could and could not be removed from the body for inspection. A dissection was the examination of all possible parts of the interior of the human body for scientific and anatomical knowledge. By the end of the thirteenth century, dissection was being used by medical experts throughout Europe in order to train students in the workings of the body. ${ }^{109}$ This meant that there would be a crowd of students surrounding the body, watching the dissector's every move. Typically, these were done in the confines of a university setting. Later there were laws put in place regarding aspects of human dissections, particularly in regard to where the bodies to be dissected came from, the act of dissection was not a taboo one. The prevalent myth that the medieval Christian church entirely prohibited human dissection was untrue. ${ }^{110}$ This myth was due to nineteenth-century historiography with a bias intent on making the nineteenth century appear modern compared to the religious and superstitious ways of the Middle Ages. ${ }^{111}$ The medieval Church did not prohibit dissection, and neither did the early modern Church. Until the middle of the sixteenth century, there was little public or private concern regarding anatomical practice and dissection in Italy, and even then, the concern was met with considerable enthusiasm for the public spectacle of

\footnotetext{
108 Toby E. Huff, The Rise of Early Modern Science: Islam, China, and the West, Second Edition (Cambridge, Cambridge University Press, 2003), 195.

${ }^{109}$ Ibid., 196.

${ }^{110}$ Katharine Park, "Holy Autopsies: Saintly Bodies and Medical Expertise, 1300-1600," in The Body in Early Modern Italy, ed. by Julia L. Hairston and Walter Stephens (Baltimore: The Johns Hopkins University Press, 2010), 61.

111 Ibid., 61.
} 
dissection. ${ }^{12}$ Even this public concern was remarkably benign, compared to what later historians would write about the supposed outrage over dissections. There was no religious outrage against dissections or autopsies. The only upsetting activity would be a dissection that would go against societal norms.

The early modern period can be defined as a period of great anxiety. ${ }^{113}$ From the fractured religious polity wrought by Protestantism to the exploration and founding of a New World, the people of Early Modern Europe were concerned about what seemed to be a rapidly changing world. In order to placate themselves, they relied upon the adherence to social norms in order to try to retain control of what they could. Any behavior that would go against these norms would upset the populace. So any anger over dissections that later nineteenth-century historians may have reported was certainly not due to religious issues, but simply due to societal norms being transgressed, just like in many witch trials. The dissection and study of the body was never the central cause for concern, and in many cases lessened anxiety either in an explicit or implicit manner.

While university-sanctioned dissections occurred on both male and female bodies, if the possibility for a female corpse arose, the holy autopsy remained in the realm of the female faithful, well until the early sixteenth century. ${ }^{114}$ The best evidence against the existence of any sort of ecclesiastical ban on the opening of corpses comes from the proliferation of so-called holy autopsies. A holy autopsy was the practice of opening the body and inspecting the internal organs of a holy person after their death to search for physically visible signs of sanctity such as those used as proof in hagiographical texts and

\footnotetext{
${ }^{112}$ Katharine Park, "The Criminal and the Saintly Body: Autopsy and Dissection in Renaissance Italy," 18.

${ }^{113}$ William J. Bouwsma, A Usable Past: Essays in European Cultural History. (Berkeley: University of California Press, 1990), 159.

${ }^{114}$ Katharine Park, "Holy Autopsies: Saintly Bodies and Medical Expertise, 1300-1600,” 62.
} 
for evidence in papal canonizations. ${ }^{115}$ These female holy autopsies were not only unproblematic for the Church, but they were key to a Church-sanctioned activity. Women who were subjected to holy autopsies were already in the process of becoming saints. By giving them autopsies, proof could be given to the Pope in order to initiate beatification. These women were special to the public and the Church. Their special nature was believed to manifest itself in their physical body, whether internally or externally, in a process similar to that of a devil mark. The belief was that if the woman was holy, then perhaps God had blessed her and marked her as one of His own, just like if a woman was truly a witch, she would have some sort of diabolic mark placed upon her by Satan. Both the marks found in holy autopsies and on witches were of a supernatural origin, just opposing sides.

One such story of a holy autopsy, that of Chiara of Montefalco, is a useful example of what typically occurs in the accounts of these autopsies. Chiara's case is actually the first recorded holy autopsy that has been found. ${ }^{116}$ Chiara of Montefalco, the abbess of an Umbrian monastery, died on August 17, 1308. After five days in the open, with no attempt to preserve it, her body did not begin to decompose; it remained completely uncorrupted. Eventually, the sisters decided to preserve Chiara's body and began to eviscerate her. According to the narrative, a Sister Francesca of Foligno and two Illuminata named Marina and Elena, cut open the body and removed her heart, which they decided to cut open. Inside they found the image of a crucifix. They cut into the heart multiple other times and found more images, including a crown of thorns, the whip and column, the rod and sponge, and even nails. They cut open other organs and found

\footnotetext{
${ }^{115}$ Ibid., 62.

${ }^{116}$ Katharine Park, "Holy Autopsies: Saintly Bodies and Medical Expertise, 1300-1600," 62.
} 
similar signs of sanctity. ${ }^{117}$ In Chiara's case, each sign found within her heart was an image associated with the crucifixion and the suffering of Christ. These signs found in Chiara's heart were physical proof of the positive realm of the supernatural.

In the cases of Colomba of Rieti (d. 1501) and Elena Duglioli (d. 1520), which occurred over two centuries after the autopsy of Chiara of Montefalco, the signs of sanctity were subtler. In Chiara's case, and other cases during the late medieval period, the signs of sanctity were quite apparent, whereas in the later years of holy autopsies, the signs were much less visible and obvious. ${ }^{118}$ Still, the signs of holiness were manifested within the physical body, which meant in order to gain definitive proof of the holiness, an autopsy must be performed. There were no crucifixes or mystical designs appearing in Colomba's or Elena's internal organs, and there were no miraculously preserved bodies after days in the hot summer heat. As the years progressed, and medicine progressed with them, the signs of holiness became less obvious because those doing the autopsy were more accustomed to the interior anatomy of a human being, meaning the signs of sanctity did not have to be as visible as before. The proliferation of dissections made holy autopsies became a much more scientific affair. There were doctors present instead of nuns and priests, and the bodies were not simply opened because of curiosity; they were opened to be embalmed, and an autopsy was requested while the body was already opened. The autopsies of Colomba and Elena were also tied closely to their embalming, but the medical context had changed drastically by that time compared to Chiara's autopsy. Their bodies were opened at a time where there was a great expansion of the

\footnotetext{
${ }^{117}$ Katharine Park, "The Criminal and the Saintly Body: Autopsy and Dissection in Renaissance Italy," 1-2.

${ }^{118}$ Katharine Park, "Holy Autopsies: Saintly Bodies and Medical Expertise, 1300-1600,” 65.
} 
practice of human autopsy and dissection in Italy. ${ }^{119}$ With these new holy autopsies came new responsibilities for the person performing the autopsy. The findings of the autopsies raise meaningful questions about both the natures of evidence and proof and also of contemporary understandings of the physical nature of holy bodies. ${ }^{120}$ The early modern holy autopsies raised the level of proof required for a holy autopsy to be conclusive of sanctity.

Colomba of Rieti, a devout Dominican, was opened for embalming by a doctor, and had an autopsy during her embalming. ${ }^{121}$ During her autopsy, it was found that, "her stomach and intestines were almost empty, which confirmed reports that she lived exclusively from the Eucharist, and, second, that her heart was bathed in un-congealed blood. In [her confessor's] words, this was 'liquid, full of life, bright and pure, as if it had flowed from the throat of a living dove.",122 This is noticeably different from Chiara's autopsy. First, Colomba's body was opened not because it was believed to contain signs of holiness, but simply for curiosity during her embalming. Everything done during Colomba's autopsy was routine until the miraculous signs of her empty intestines and her un-congealed blood were found. Secondly, Colomba's body was not marked by holiness in the same way as Chiara's. While Chiara's heart was said to have contained markings of Christ's suffering, Colomba's body was simply unusual and free from easily identified images. Colomba's autopsy showed evidence for her sanctity by lack of what was found. In other words, the lack of digested food in her stomach was proof of a claim made during her life of extreme fasting, which in turn was found as proof that Christ Himself

\footnotetext{
119 Ibid., 64.

${ }^{120}$ Ibid., 63.

${ }^{121}$ Katharine Park, "Holy Autopsies: Saintly Bodies and Medical Expertise, 1300-1600,” 66.

122 Ibid., 66.
} 
was sustaining her, since she lacked all other nutrients. Also, the emphasis on the vitality and color of Colomba's blood was seen as proof of both the special nature of her body and the uncorrupted nature of her soul. By stating that her blood looked as pure as if it had flowed through a dove, the author was comparing her blood to the blood of an incredibly important symbol in Christianity- the dove. Since the dove was used to represent the Holy Spirit, Colomba was in holy company.

Elena Duglioli's autopsy was similar to Colomba's in that it was clear that the autopsy was conducted by a trained practitioner. Elena was a pious laywoman who reportedly remained a virgin her entire life, even after marriage. She never had a child, but she miraculously began to produce milk and menstruated until late in life. While still alive, Elena would allow her followers to suckle from her breasts so they could ingest what was believed to be a miracle from Christ himself. After her death, her body was embalmed and autopsied by multiple educated men in the presence of a doctor. The autopsy immediately furnished incredible results, for in the place of Elena's heart, there was a pale, flat, and flaccid lump. This mass was described in the original text as being "like a piece of soft liver." The main dissector noted that "it was so unlike a heart that someone familiar with that human organ would never have recognized it as a heart. And the doctors in attendance said that it was a very strange thing that they had never heard of anything like it." ${ }^{123}$ According to legend, her confessor said that this was because Elena had claimed that Christ had taken her heart to heaven so it would not cause her any more physical pain. While Elena was not a nun, she remained holy due to her status as a virgin, even after marriage. Additionally, Elena was able to take on at least one important aspect

\footnotetext{
${ }^{123}$ Katharine Park, "Holy Autopsies: Saintly Bodies and Medical Expertise, 1300-1600,” 67.
} 
of motherhood without having to corrupt her virginal status. By producing milk, Elena was in a way able to feed her followers with her body, similar to the way a mother would feed her child. This instance in particular is striking when contrasted with the belief in witches' teats as discussed previously in this thesis. Both the witches accused of having demonic nipples and Elena Duglioli were able to feed others with their bodies outside of motherly commitments. Where Elena produced milk and fed followers through her own breasts, witches produced extra nipples and fed their familiars with blood, in direct contrast to proper mothers. Whether it be in a demonic sense or in a holy sense, food, and breastfeeding specifically, were important physical symbols.

In her book Holy Feast, Holy Fast: The Religious Significance of Food to Medieval Women, Caroline Walker Bynum suggested that eating or rejecting food was a way for women to attempt to control aspects of their lives. In the spiritual belief and tradition of late medieval Europe, diet, both eating and not eating, was an important symbol. ${ }^{124}$ By only taking in the holy Eucharist and rejecting all other food, Colomba was attempting to gain control over her own body. Similarly, Elena's ability to produce milk outside of motherhood and feed others showed her control over her own body. The importance of control over one's own body, however, is not limited to the diet of a holy woman. As mentioned previously, witches or other demoniacs lost control over their own bodies. Often the possessed would be moved to eat inedible substances, including dirt, nails, and other materials. For holy women, not eating was a sign of purity, and for demoniacs, eating unusual objects was a sign of both a lack of control over their bodies and of their devotion to Satan. Both represented opposing sides of the supernatural.

\footnotetext{
${ }^{124}$ Caroline Walker Bynum, Holy Feast and Holy Fast: The Religious Significance of Food to Medieval Women (Berkeley and Los Angeles: University of California Press, 1987), 73.
} 
Regardless of what the evidence was used to prove, the physical nature of eating and of food was seen as a very important piece of evidence in both witchcraft trials and holy autopsies.

At the center of popular Christian belief, as Chiara of Montefalco's story proves, are relics, and particularly the dead and often dismembered bodies of saints. The association between dismemberment and sanctity continued in popular attitudes into the sixteenth century and can help to explain the Italian tolerance of anatomy and dissection. ${ }^{125}$ Death was acknowledged as a part of life, so the bodies of the dead were not things that made the living uncomfortable. From the beginning of the twelfth century, opening the body after death was a common funerary practice. Throughout the fourteenth century this focus on dissection also became increasingly popular in Italian medicine, even becoming so widespread that it became requested by individuals and their families as part of the funerary rituals. It was only in the middle of the sixteenth century that there began to be a sort of suspicion surrounding the popularity of dissections. ${ }^{126}$ This suspicion in the interest in the body was not because of a long-standing aversion towards dissection or towards examining the physical body. There were certainly instances of families objecting to autopsies, but not because the idea of the physical body was repellant, since there was no prohibition towards opening dead bodies. ${ }^{127}$ It remained a tendency for later nineteenth-century historians to believe that the people of the Early Modern age were superstitious or otherwise religiously influenced to be afraid of autopsies. The antiquaries and folklorists who were writing about past beliefs in the dead

\footnotetext{
${ }^{125}$ Katharine Park, "The Criminal and the Saintly Body: Autopsy and Dissection in Renaissance Italy," 22.

${ }^{126}$ Ibid., 4.

${ }^{127}$ Ibid., 10
} 
body had unclear motivations. They were living in a time of great change, where customs and beliefs they found interesting, if not outdated, were disappearing. They were observing and writing about customs they had most likely never taken part of and saw as foreign, which is reflected in the way in which they wrote about them. ${ }^{128}$ So from the start, the first people writing about the Early Modern period's beliefs regarding bodies, autopsies, and dissections, had a bias. These people were attempting to prove their superiority over the past generations by regarding their quaint beliefs with mockery in comparison to their own. By making the Early Modern period seem like a time filled with superstition and unease in regard to human bodies, the historians of the eighteenth and nineteenth centuries instantly made their society seem more sophisticated by comparison.

In both the study of witchcraft trials and in the study of holy autopsies, it is obvious that women were treated inherently different than men. Not only were women treated uniquely different, but even their physical bodies were treated differently than those of their male counterparts. As early as the fourteenth century, the availability of a female cadaver at a scholastic autopsy was unique and exciting, even drawing a crowd. By the fifteenth century these postmortems became even more common for men and women alike. ${ }^{129}$ This unequal view of male and female bodies is something many historians researching the body notice, whether in its physical or its metaphorical form. Partially due to religious values and partially due to societal constraints, women's bodies were much more mysterious than those of men. Female bodies were not only difficult to obtain, but they were also more uncomfortable for the male doctor dissecting to view.

\footnotetext{
${ }^{128}$ Ruth Richardson, Death, Dissection and the Destitute, Second Edition (Chicago: The University of Chicago Press, 1987), 5.

${ }^{129}$ Monica H. Green, Making Women's Medicine Masculine: The Rise of Male Authority in Pre-Modern Gynaecology (Oxford: Oxford University Press, 2008), 257.
} 
The anatomist, by very necessity, had to be conscious of how his work on women's bodies might have been viewed. ${ }^{130}$ The anatomist could not afford a bad reputation, particularly when they were already dealing with something as uncommon as dissecting cadavers. In order to remain free from ill repute, dissections had to be done under specific circumstances, and typically with an audience of students.

Aside from not being dissected often for fear of impropriety, women were generally not treated well when it came to medicine. Because women's bodies could not be studied, doctors did not know entirely what occurred in their female patients. In return, women were left in limbo in regard to medicine. Women, who knew their bodies much better than their male physicians, were unable to attend medical school because of societal gender norms, but their doctors were also not allowed to study their bodies in order to learn about them. For women in early modern Europe, there were very few options available. Most often, women simply were not studied. Women were excluded from the institutions and intellectual traditions of western medicine when it was establishing its most important features: the basis of medical science on natural philosophy and the standardizing of that knowledge. ${ }^{131}$ Women were both excluded from the tradition of medicine by not being studied and by not being able to join the academic discipline itself. Late medieval and early modern women's medicine was deliberately gendered against women. ${ }^{132}$ Information about female medicine, such as female anatomy, pregnancy, and even the feminine reproductive cycle was used and manipulated by a

\footnotetext{
${ }^{130}$ Helen MacDonald, Human Remains: Episodes in Human Dissection (Victoria, Australia: Melbourne University Press, 2005), 6.

${ }^{131}$ Monica H. Green, Making Women's Medicine Masculine: The Rise of Male Authority in Pre-Modern Gynaecology (Oxford: Oxford University Press, 2008), 27.

${ }^{132}$ Ibid., 316.
} 
patriarchal society which considered it powerful information. While powerful, it was also considered problematic, since all of that knowledge concerned discussions of sex. ${ }^{133}$ While polite doctors did not deem it appropriate to discuss female sexuality, the demonologists of the time certainly were preoccupied with it. Female sexuality informed the way traditional gender roles were created and enforced. Women who strayed from traditional gender roles were seen as bad women, and most likely engaged in other secretive bad behavior. The demonologist's conclusion then was that women as bad as witches must engage in sexual behavior equally as bad as the maleficium they performed. Sexuality, which was a very physical act, was also used as proof of both holiness and evil.

${ }^{133}$ Ibid., 316. 


\section{CONCLUSION}

Whether it be witches or saints, the study of the body served a great purpose in providing physical evidence for trials in the late medieval and early modern period. The importance placed on the physical body was echoed in witch trials and canonization trials alike. While the signs demonologists and priests looked for were entirely different, the belief in them stemmed from the same place. With the belief in these types of physical proofs was a belief in the supernatural. Without the underlying belief in the supernatural, the signs on or in the human body would have no meaning. Ultimately, supernatural forces beyond true human comprehension were believed to have placed the signs on the body.

By studying accounts of holy autopsies, witchcraft trial records, and demonology, this thesis has demonstrated a clear relationship between a strict belief in the power of the supernatural and a belief in the use of the physical body as a piece of evidence. Similarly, there is a parallel between the types of evidence used for demonologists, witch hunters, and priests searching for saints. As shown throughout this thesis, physical evidence such as strip searches, autopsies, and even diet, among others, were all used as proof of a supernatural effect on a person. While the signs for witchcraft and sanctity were understandably different, the places and ways the signs appeared were remarkably similar. The physicality of the proof utilized by demonologists echoed the physicality of the proof found during holy autopsies. This proves the reliance and trust placed in 
physical evidence. It also is an example of the belief that supernatural forces could affect humans in visible and invisible ways that could then be detected by searching the body. Even the torture applied by interrogators to accused witches is proof of the importance of the physical body. Particularly in the search for the devil mark, which meant the body must be pricked by a pin continuously, the physical body was the ultimate authority when it came to proof. The fear of witchcraft surrounded the late medieval and Early Modern community. Medical evidence held a central role in both witch trials and holy autopsies, showing the priority scientific evidence held in early modern European courts.

In the examination of demonological texts and witch trial records in this thesis, the emphasis placed on the body is clear. In demonological texts, not only was the body of the witch under scrutiny, but the physical damage the witch could cause, to both themselves and the community, was covered in depth. Demonologists focused on the physical nature of the crime of witchcraft to prove the existence of the supernatural. This was due to the early creation of a link between witchcraft and heresy, which meant that the physical crimes of heretics were also applied to witches. The physicality of the crime was echoed in the physicality of the proof. Similarly, in trial records, the body of an accused witch was used as evidence of nefarious behavior. By initiating strip searches and utilizing torture, the body was of key importance in the trials. Whether it be finding devil marks, witches' teats, or physical deformities, trial records show that the physical body of a witch was of key importance in proving the existence of the supernatural. Medical evidence held importance in both witch trials and holy autopsies, showing the priority scientific evidence held in early modern European courts. 
Without the emphasis placed on both the physical nature of witchcraft and holiness, witch trials would have taken a completely different form. As it stands, physical evidence was the most important aspect of any trial, because physical proof on the human body of either witchcraft or holiness was the closest to a definitive proof of the supernatural any human could obtain. The study of both the body and of witchcraft theory merged together to create the type of statutory evidence needed to prove the existence of the supernatural in a court of law. In a time defined by uncertainty, anxiety, and constant change, the ability to prove the existence of the supernatural with physical evidence shaped the nature of criminal courts and autopsies irrevocably. In both witch trials and holy autopsies, supernatural forces were believed to be at work. Whether it was a witch marred with a devil mark or a pious woman with signs of her holiness within her own body, the physical evidence provided by the body gave early modern Europeans proof of the supernatural. Medieval and early modern witchcraft trials and holy autopsies were changed with the capability to prove the existence of the supernatural with physical proof. 


\section{REFERENCES}

Apps, Lara and Andrew Gow. Male Witches in Early Modern Europe. Manchester and New York: Manchester and University Press, 2003.

Asad, Talal. "Medieval Heresy: An Anthropological View." Social History 11, 3 (October 1986): 345-362.

Bailey, Michael D. Magic and Superstition in Europe: A Concise History from Antiquity to the Present. Lanham, Maryland: Rowman \& Littlefield Publishers, Inc., 2007.

- Battling Demons: Witchcraft, Heresy, and Reform in the Late Middle Ages. University Park, Pennsylvania: The Pennsylvania State University Press, 2003.

Bardsley, Sandy. Women's Roles in the Middle Ages. Westport, Connecticut: Greenwood Press, 2007.

Behringer, Wolfgang. Witchcraft Persecutions in Bavaria: Popular Magic, Religious Zealotry and Reason of State in Early Modern Europe. Translated by J. C. Grayson and David Lederer. Cambridge: Cambridge University Press, 1997.

Bever, Edward. "Witchcraft Prosecutions and the Decline of Magic." The Journal of Interdisciplinary History 40, 2 (autumn 2009): 263-293.

Bouwsma, William J. A Usable Past: Essays in European Cultural History. Berkeley: University of California Press, 1990.

Briggs, Robin. "Dangerous Spirits: Shapeshifting, Apparitions, and Fantasy in Lorraine Witchcraft Trials," in Werewolves, Witches, and Wandering Spirits: Traditional Belief \& Folklore in Early Modern Europe, Edited by Kathryn A. Edwards, 1-24. Kirksville, MO: Truman State University Press, 2002.

- Witches \& Neighbors: The Social and Cultural Context of European Witchcraft. New York: Viking, 1996.

Broedel, Hans Peter. The Malleus Maleficarum and the Construction of Witchcraft:

Theology and Popular Belief. Manchester: Manchester University Press, 2003. 
Caciola, Nancy. Discerning Spirits: Divine and Demonic Possession in the Middle Ages. Ithaca and London: Cornell University Press, 2003.

Campagne, Fabián Alejandro. "Demonology at a Crossroads: The Visions of Ermine de Reims and the Image of the Devil on the Eve of the Great European Witch-Hunt." Church History 80, 3 (September 2011): 467-497.

Clark, Stuart. Thinking with Demons: the Idea of Witchcraft in Early Modern Europe. Oxford: Oxford University Press, 1997.

Clasen, Claus-Peter. "Medieval Heresies in the Reformation." Church History 32, 4 (December 1963): 392-414.

Cohn, Norman. Europe's Inner Demons: The Demonization of Christians in Medieval Christendom. Chicago: The University of Chicago Press, 1993.

Cregan, Kate. The Theatre of the Body: Staging Death and Embodying Life in EarlyModern London. Turnhout, Belgium: Brepols Publishers, 2009.

Darr, Orna Alyagon. "Experiments in the Courtroom: Social Dynamics and Spectacles of Proof in Early Modern English Witch Trials." Law \& Social Inquiry 39, 1 (Winter 2014): 152-175.

- Marks of an Absolute Witch: Evidentiary Dilemmas in Early Modern England. Burlington, VT: Ashgate Publishing Company, 2011.

Davies, Owen. Witchcraft, Magic and Culture: 1736-1951. Manchester and New York: Manchester University Press, 1999.

De La Torre, Miguel A., and Albert Hernández. The Quest for the Historical Satan. Minneapolis, MN: Fortress Press, 2011.

Ferber, Sarah. Demonic Possession and Exorcism in Early Modern France. London and New York: Routledge, 2004.

Garrett, Julia M. "Witchcraft and Sexual Knowledge in Early Modern England." Journal for Early Modern Cultural Studies 13, 1 (Winter 2013): 32-72.

Gaskill, Malcolm. "The Pursuit of Reality: Recent Research into the History of Witchcraft.” The Historical Journal 51, 4 (December 2008): 1069-1088.

_. "Witchcraft and Evidence in Early Modern England." Past \& Present 198 (February 2008): 33-70.

Witchfinders: A Seventeenth-Century English Tragedy. Cambridge: Harvard University Press, 2005. 
Gibson, Marion. Early Modern Witches: Witchcraft Cases in Contemporary Writing. London and New York: Routledge, 2000.

- Reading Witchcraft: Stories of Early English Witches. London and New York: Routledge, 1999.

Goodare, Julian. The European Witch-Hunt. London and New York: Routledge, 2016.

Green, Monica H. Making Women's Medicine Masculine: The Rise of Male Authority in Pre-Modern Gynaecology. Oxford: Oxford University Press, 2008.

Guazzo, Francesco Maria. Compendium Maleficarum. Translated by Montague Summers. New York: Dover Publications, Inc., 1988.

Huff, Toby E. The Rise of Early Modern Science: Islam, China, and the West. Second Edition. Cambridge: Cambridge University Press, 2003.

Karlen, Arno. "The Homosexual Heresy.” The Chaucer Review 6, 1 (Summer 1971): 44-63.

Kent, E.J. Cases of Male Witchcraft in Old and New England, 1592-1692. Turnhout, Belgium: Brepols, 2013.

Kerr, Margaret H, Richard D. Forsyth, and Michael J. Plyley. "Cold Water and Hot Iron: Trial by Ordeal in England." The Journal of Interdisciplinary History 22, 4 (Spring 1992): 573-595.

Kieckhefer, Richard. Forbidden Rites: A Necromancer's Manual of the Fifteenth Century. University Park, Pennsylvania: The Pennsylvania State University Press, 1997.

_. Magic in the Middle Ages. Cambridge: Cambridge University Press, 1989.

Klassen, Frank. The Transformations of Magic: Illicit Learned Magic in the Later Middle Ages and Renaissance. Universtiy Park, Pennsylvania: The Pennsylvania State University Press, 2013.

Kramer, Heinrich and James Sprenger. Malleus Maleficarum. Translated by Rev. Montague Summers. New York: Dover Publications, Inc., 1971. Langbein, John H. Torture and the Law of Proof: Europe and England in the Ancient Régime. Chicago: The University of Chicago Press, 2006.

Levack, Brian P. The Witch-Hunt in Early Modern Europe, Fourth Edition. London and New York: Routledge, 2016.

Lindemann, Mary. Medicine and Society in Early Modern Europe. Cambridge: 
Cambridge University Press, 1999.

MacDonald, Helen. Human Remains: Episodes in Human Dissection. Victoria, Australia: Melbourne University Press, 2005.

Mair, Lucy. "Witchcraft, Spirit Possession and Heresy." Folklore 91, 2 (1980): 228-238.

Mäkinen, Virpi and Heikki Pihlajamäki. “The Individualization of Crime in Medieval Canon Law." Journal of the History of Ideas 65, 4 (October 2004): 525-542.

McCaffrey, Emily. "Imagining the Cathars in Late-Twentieth-Century Languedoc." Contemporary European History 11, 3 (August 2002): 409-427.

Midelfort, H.C. Erik. Witch Hunting in Southwestern Germany, 1562-1684: The Social and Intellectual Foundations. Stanford, CA: Stanford University Press, 1972.

Monsieur des Niau. "On the Possessed Nuns of Loudun (1634)." In The Occult in Early Modern Europe: A Documentary History, edited and translated by P. G. Maxwell Stuart, 179-180. New York: St. Martin's Press, 1999.

Monter, William. "Toads and Eucharists: The male witches of Normandy, 1564-1660." French Historical Studies 20, 4 (1997): 563-595.

Moore, R. I. “The Origins of Medieval Heresy.” History 55, 183 (1970): 21-36.

Naish, Camille. Death Comes to the Maiden: Sex and Execution 1431-1933. London: Routledge, 1991.

Nicholson, Helen. The Knights Templar: A Brief History of the Warrior Order. London: Constable \& Robinson, 2010.

O'Brien, Sheilagh Ilona. “The Discovery of Witches: Matthew Hopkins's Defense of his Witch-Hunting Methods." Preternature: Critical and Historical Studies on the Preternatural 5, 1 (2016): 29-58.

Park, Katharine. "The Criminal and the Saintly Body: Autopsy and Dissection in Renaissance Italy." Renaissance Quarterly 47, 1 (Spring 1994): 1-33.

—_. "Holy Autopsies: Saintly Bodies and Medical Expertise, 1300-1600." In The Body in Early Modern Italy, edited by Julia L. Hairston and Walter Stephens, 6173. Baltimore, MD: The Johns Hopkins University Press, 2010.

- Secrets of Women: Gender, Generation, and the Origins of Human Dissection. New York: Zone Books, 2006.

Peters, Edward. Torture: Expanded Edition. Philadelphia: University of Pennsylvania 
Press, 1996.

Pihlajamäki, Heikki. "Swimming the Witch, Pricking for the Devil's Mark': Ordeals in the Early Modern Witchcraft Trials.” Legal History, 21, 2 (August 2000): 35-58.

Pomata, Gianna. "Malpighi and the Holy Body: Medical Experts and Miraculous Evidence in Seventeenth-Century Italy.” Renaissance Studies 21, 4 (September 2007): 568-586.

Rapley, Robert. A Case of Witchcraft: The Trial of Urbain Grandier. Montreal: McGillQueen's University Press, 1998.

Rémy, Nicolas. Demonolatry. Translated by E. A. Ashwin, Edited by Rev. Montague Summers. New York: Barnes \& Noble, Inc., 1970.

Richardson, Ruth. Death, Dissection and the Destitute. Second Edition. Chicago: The University of Chicago Press, 1987.

Robbins, Rossell Hope. “The Imposture of Witchcraft.” Folklore 74, 4 (1963): 545-562.

Roper, Lyndal. "Witchcraft and the Western Imagination." Transactions of the Royal Historical Society sixth series, 16 (2006): 117-141.

Russell, Jeffrey Burton. Lucifer: The Devil in the Middle Ages. Ithaca and London: Cornell University Press, 1984.

Simpson, James. "No Brainer: The Early Modern Tragedy of Torture." Religion \& Literature 43, 3 (autumn 2011): 1-23.

Stephens, Walter. Demon Lovers: Witchcraft, Sex, and the Crisis of Belief. Chicago and London: The University of Chicago Press, 2002.

Sugg, Richard. Murder After Death: Literature and Anatomy in Early Modern England. Ithaca, New York: Cornell University Press, 2007.

Thomas, Keith. Religion and the Decline of Magic: Studies in Popular Beliefs in Sixteenth and Seventeenth Century England. London: Penguin, 2003.

von Langenfield, Friedrich Spee. Cautio Criminalis, or a Book on Witch Trials, Edited by Marcus Hellyer. Charlotsville, VA, 2003, in The Witchcraft Sourcebook, Edited by Brian P. Levack. New York and London: Routledge, 2004.

Thomsett, Micahel C. Heresy in the Roman Catholic Church: A History. Jefferson, N.C.: McFarland, 2011.

Walker Bynum, Caroline. "Bodily Miracles and the Resurrection of the Body in the High 
Middle Ages." In Belief in History: Innovative Approaches to European and American Religion, edited by Thomas Kselman, 68-106. Notre Dame, Indiana: University of Notre Dame Press, 1991.

- Fragmentation and Redemption: Essays on Gender and the Human Body in Medieval Religion. New York: Zone Books, 1991.

- Holy Feast and Holy Fast: The Religious Significance of Food to Medieval Women. Berkeley and Los Angeles: University of California Press, 1987.

- The Resurrection of the Body in Western Christianity, 200-1336. New York: Columbia University Press, 1995.

. "Why All the Fuss About the Body? A Medievalist's Perspective." Critical Inquiry 22, 1 (Autumn 1995): 1-33. 


\section{CURRICULUM VITA}

NAME:

ADDRESS:

DOB:

EDUCATION

\& TRAINING:
Sarah Marie Dunn

2312 West Pineview Drive

Muncie, IN 47303

Muncie, Indiana - August 14, 1992

University of Louisville

Masters Candidate in History, 2015-present

Major Field: European History

(Dr. Blake Beattie)

Minor Field: Ancient and Medieval World

Thesis: The Mark of the Devil: Medical Proof in Witchcraft Trials

University of Louisville

B.A., History cum laude

2010-2014

University of Louisville

B.A., Humanities cum laude

Fields: Medieval and Renaissance Studies

2010-2014

AWARDS: $\quad$ Newberry Library Renaissance Consortium Travel and Research Grant

January 2017

Graduate Teaching Assistantship (2016-2017)

History Department, University of Louisville

Graduate Assistantship (2015-2016)

History Department, University of Louisville
PROFESSIONAL SOCIETIES:
University of Louisville Graduate Student Council (2015-2017)

Phi Alpha Theta, Nu Xi Chapter 
Sigma Alpha Lambda Honor Society

Golden Key Honor Society

PRESENTATIONS: Louisville Medieval and Renaissance Group Workshop, "Late Medieval Demonology and the Formation of European Witchcraft Belief"'

February 2017

Newberry Library Graduate Student Conference, "The Body of a Witch: Examining Medical Evidence of Witchcraft in Late Renaissance and Early Modern Witch Trials" January 2017 